Review

\title{
Coupling Noble Metals and Carbon Supports in the Development of Combustion Catalysts for the Abatement of BTX Compounds in Air Streams
}

\section{Sergio Morales-Torres, Francisco Carrasco-Marín, Agustín F. Pérez-Cadenas and Francisco José Maldonado-Hódar *}

Department of Inorganic Chemistry, Faculty of Sciences. University of Granada, Avda. Fuentenueva s/n. 18071, Spain; E-Mails: semoto@fe.up.pt (S.M.-T.); fmarin@ugr.es (F.C.-M.); afperez@ugr.es (A.F.P.-C.)

* Author to whom correspondence should be addressed; E-Mail: fjmaldon@ugr.es; Tel.: +34-9582-40444; Fax: +34-9582-48526.

Academic Editor: Jean-François Lamonier

Received: 24 February 2015 / Accepted: 17 April 2015 / Published: 27 April 2015

\begin{abstract}
The catalytic combustion of volatile organic compounds (VOCs) is one of the most important techniques to remove these pollutants from the air stream, but it should be carried out at the lowest possible temperature, saving energy and avoiding the simultaneous formation of nitrogen oxides $\left(\mathrm{NO}_{x}\right)$. Under these experimental conditions, the chemisorption of water generated from VOCs combustion may inhibit hydrophilic catalysts. Nowadays, a wide variety of carbon materials is available to be used in catalysis. The behavior of these hydrophobic materials in the development of highly active and selective combustion catalysts is analyzed in this manuscript. The support characteristics (porosity, hydrophobicity, structure, surface chemistry, etc.) and the active phase nature (noble metals: $\mathrm{Pt}, \mathrm{Pd}$ ) and dispersion were analyzed by several techniques and the results correlated with the dual adsorptive and/or catalytic performance of the corresponding catalysts. The coupling of highly active phases and carbon materials (activated carbons, honeycomb coated monoliths, carbon aerogels, etc.) with tuneable physicochemical properties leads to the complete abatement of benzene, toluene and xylenes (BTX) from dilute air streams, being selectively oxidized to $\mathrm{CO}_{2}$ at low temperatures.
\end{abstract}

Keywords: carbon materials; noble metals; combustion catalyst; porosity; surface chemistry; sensitive reaction 


\section{Introduction}

Volatile organic compounds (VOCs) are compounds with boiling point ranging from $\left(50-100{ }^{\circ} \mathrm{C}\right)$ to $\left(240-260^{\circ} \mathrm{C}\right.$ ), which corresponds to saturation vapor pressures larger than $102 \mathrm{kPa}$ at $25^{\circ} \mathrm{C}$ [1]. Most VOCs are toxic to both humans and the environment. In fact, the tropospheric ozone and the photochemical smog are formed when VOCs are exposed to nitrogen oxides $\left(\mathrm{NO}_{x}\right)$ and sunlight. These pollutants are present outdoor and indoor. Some indoor sources include solvents used in the building and maintenance of construction materials, furnishings, office equipment and consumer products.

The overall catalytic oxidation (typically referred to as combustion) is one of the most effective VOCs removal technologies, since it operates with dilute concentrations of VOCs and at lower temperature than traditional thermal incinerators. The employ of catalysts allows significantly decreasing the operating temperature and the formation of undesirable by-products (e.g., dioxins and $\mathrm{NO}_{x}$ ), as well as saving energy [2].

Combustion catalysts are commonly based on noble metals ( $\mathrm{Pt}, \mathrm{Pd}, \mathrm{Rh}, \mathrm{Au}$ and $\mathrm{Ag}$ ), transition metal oxides (Ni, Cu, Co, Cr, Mn, Mo, V, Zn, Zr, Ce, Ti and Fe) and their mixtures (e.g., $\mathrm{MnO}_{x}-\mathrm{CuO}_{x}$ and $\mathrm{MnO}_{x}-\mathrm{CeO}_{2}$ ) [3-9]. Catalysts based on transition metal oxides are much cheaper than noble metals and can be quite active in the oxidation of determined VOCs. Manganese oxides $\left(\mathrm{MnO}_{x}\right)$ are the most widely studied metal oxides due to the high activity, stability, relative low toxicity and redox properties. In fact, $\mathrm{Mn}$ atoms have a strong ability of switching oxidation states $(+\mathrm{II},+\mathrm{III},+\mathrm{IV})$ and forming structural defects, which lead to a high oxygen mobility and storage [2]. In the catalytic oxidation of benzene and toluene over $\mathrm{MnO}_{x}$-based catalysts (i.e., $\mathrm{Mn}_{3} \mathrm{O}_{4}, \mathrm{Mn}_{2} \mathrm{O}_{3}$ and $\mathrm{MnO}_{2}$ ), the trend of catalytic activity was as follows: $\mathrm{Mn}_{3} \mathrm{O}_{4}>\mathrm{Mn}_{2} \mathrm{O}_{3}>\mathrm{MnO}_{2}$, i.e., as the oxygen mobility of the $\mathrm{MnO}_{x}$ catalyst [10]. Cryptomelane, todorokite and pyrolusite are manganese oxides with different square tunnel structures used also in VOCs oxidation. For instance, cryptomelane $\left(\mathrm{KMn}_{8} \mathrm{O}_{16}\right)$ was very active towards the oxidation of ethanol, ethyl acetate and toluene; although its catalytic performance was influenced by the presence of other phases, in particular $\mathrm{Mn}_{2} \mathrm{O}_{3}$ and $\mathrm{Mn}_{3} \mathrm{O}_{4}$ [11]. Toluene was the least VOCs oxidized, due to the decrease of the oxygen mobility and consequently slow incorporation rate of lattice oxygen. On the other hand, ceria $\left(\mathrm{CeO}_{2}\right)$ is the ideal support in terms of outstanding oxygen storage capacity and hence, it is commonly employed as a structural and electronic promoter in catalysis [2], because oxygen molecules can be easily transferred to the $\mathrm{CeO}_{2}$ surface through a reversible redox process between $\mathrm{Ce}^{4+}$ and $\mathrm{Ce}^{3+}[12]$. Ordered mesoporous $\mathrm{CrO}_{3}$ was very active for toluene oxidation [13], but its high toxicity causes serious concerns. Supported vanadia $\left(\mathrm{V}_{2} \mathrm{O}_{5}\right)$ catalysts showed excellent activity for the simultaneous removal of VOCs and $\mathrm{NO}_{x}$ in $\mathrm{Cl}_{2}-\mathrm{HCl}$ environment [14], but their corrosive properties avoid their application. In general, catalysts based on metal oxides present often lower activity than those based on noble metals, however they are more resistant to be poisoned by halogenated compounds, As, $\mathrm{Pb}$ or $\mathrm{P}$.

In spite of the expensive cost, noble metal-based catalysts are preferred for catalytic oxidation of VOCs, because of their high specific activity, strong resistance to deactivation and ability to be regenerated [15]. However, the industrial application of these catalysts is still limited by costs and sensitivity to poisoning by chlorine/chloride products in the oxidation of chlorinated VOCs [16]. The catalytic performance of supported catalysts depends on: (i) intrinsic characteristics of the active phase (e.g., dispersion, metal loading and oxidation state); (ii) properties of support (e.g., porosity and 
hydrophobicity) and (iii) the operating parameters (e.g., concentrations of VOCs and oxygen, VOCs nature, overall flow rate, type of reactor) [15]. Pt and Pd are the most widely noble metals studied due to their high stability in severe conditions (high resistance to irreversible oxidation) and high activity in hydrocarbon oxidations $[3,17]$. Compared to $\mathrm{Pt}, \mathrm{Pd}$ is generally more active in methane conversion but worse in the transformation of other compounds [18]. Pd also exhibited higher resistance to thermal and hydrothermal sintering and its price is relatively lower. However, Pd-performance is worse than that for Pt in presence of poisons (e.g., sulfur-containing pollutants) [15], although Pd demonstrated to be less inhibited by $\mathrm{CO}$ [19]. In literature, other metals such as, Ag, Au [20-22] or bimetallic catalysts (Pt-Au) [23] were active in VOCs oxidation.

Noble metals are generally supported on transition metal oxides such as $\gamma-\mathrm{Al}_{2} \mathrm{O}_{3}, \mathrm{SiO}_{2}, \mathrm{TiO}_{2}, \mathrm{ZrO}_{2}$, $\mathrm{Fe}_{2} \mathrm{O}_{3}, \mathrm{CeO}_{2}, \mathrm{MnO}_{x}$, etc. [22,24-27]. The selection of the support is an important issue, since properties such as acid or basic character, hydrophobicity, precursor and porosity, influence on the activity of the supported active phase. In this context, $\gamma-\mathrm{Al}_{2} \mathrm{O}_{3}$ and $\mathrm{CeO}_{2}$ were widely studied due to the large stability and surface area, which increases the metal dispersion and VOCs adsorption. Supports with acid strength, namely $\gamma-\mathrm{Al}_{2} \mathrm{O}_{3}, \mathrm{SiO}_{2}$ and $\mathrm{ZrO}_{2}$, improved the catalytic performance over supported $\mathrm{Pt}$ and $\mathrm{Pd}$ catalysts [28,29]. Pt, $\mathrm{Rh}, \mathrm{Pd}$ and $\mathrm{Au}$ catalysts supported on $\mathrm{TiO}_{2}$ showed high conversions in VOCs oxidation, like formaldehyde, which was even oxidized at room temperature by using $\mathrm{Pt} / \mathrm{TiO}_{2}$. The performance of these noble metals supported on $\mathrm{TiO}_{2}$ was closely related to their capacities on the formation of formate species and the formate decomposition into $\mathrm{CO}$ species [30]. The oxidation of formaldehyde has also been investigated with Pt catalysts supported on $\mathrm{Fe}_{2} \mathrm{O}_{3}$ [31] and $\mathrm{MnO}_{2}$ [32]. Among noble metals, Au nanoparticles can be exceptional active when they are highly dispersed on metal oxides, such as $\mathrm{Fe}_{2} \mathrm{O}_{3}, \mathrm{Co}_{3} \mathrm{O}_{4}, \mathrm{CeO}_{2}, \mathrm{TiO}_{2}$ and $\mathrm{Mn}_{2} \mathrm{O}_{3}$ [2,22,33]. Although the catalytic performance of supported Au catalysts markedly depends on the size of Au particles and the support nature, which are affected by the synthesis method and pretreatment conditions [34]. For the case of $\mathrm{Au}$ catalysts and other noble metals, $\mathrm{CeO}_{2}$ is an excellent support due to the enhancement of the fixation and final dispersion of Au particles, and mainly the strong oxygen storage capacity which increases the mobility of the lattice oxygen and provides adequate oxidation state of $\mathrm{Au}$ particles [35]. For instance, $\mathrm{Au}$ catalysts supported on $\mathrm{CeO}_{2}$ showed better activity than those prepared on $\mathrm{TiO}_{2}$ and $\gamma-\mathrm{Al}_{2} \mathrm{O}_{3}$ for the oxidation of toluene [36]. In another study, benzene, toluene and xylenes (BTX) oxidation was studied over $\mathrm{Au}$ particles deposited on $\mathrm{ZnO}, \mathrm{Al}_{2} \mathrm{O}_{3}$ and $\mathrm{MgO}, \mathrm{Au} / \mathrm{ZnO}$ presenting higher activity than $\mathrm{Au} / \mathrm{Al}_{2} \mathrm{O}_{3}$ and finally, $\mathrm{Au} / \mathrm{MgO}$. This behavior was attributed to the strong metal-oxide interaction, which was favored from the small lattice parameter difference between $\mathrm{Au}\{111\}$ and $\mathrm{ZnO}\{101\}$ lattice planes [37]. Other supports like zeolites (MCM-41, H-ZSM-5) [38,39], pillared interlayered clays [40,41] or perovskites [42-44] were also employed as catalyst supports in the catalytic combustion of VOCs.

Water vapor is often found in industrial air streams and also is generated from VOCs oxidation. In general, water vapor is considered to act as an inhibitor of VOCs oxidation due to the blockage of active surface sites. Metal oxides have certain hydrophilic character and thereby some affinity by water, especially at low temperatures. In this context, the inhibition of supported Pt and Pd catalysts by water was already reported for the oxidation of both propane and propene [45]. This deactivation by water vapor was also observed for oxidations of ethylacetate and benzene over $\mathrm{Pt} / \gamma-\mathrm{Al}_{2} \mathrm{O}_{3}$ and $\mathrm{Pt} / \mathrm{TiO}_{2}-\mathrm{WO}_{3}$ catalysts $[17,46]$. To overcome this limitation, the use of hydrophobic supports, such as porous styrene 
divinylbenzene copolymer (SDB) was investigated for toluene oxidation [47], the catalytic activity being enhanced by expelling water from the catalyst surface, but Pt sintering being also increased.

Carbon materials are also considered an excellent hydrophobic support with high activity in VOCs oxidations (Table 1). Our research group has proposed the use of carbon materials as noble metal catalyst supports for the gas-phase combustion of VOCs. This type of support presents superior properties, such as a large surface area, high porosity, easily tuneable surface chemistry and hydrophobicity. Thus, the active sites will be deposited throughout the support, avoiding metal sintering and inhibition by water vapor at low temperatures [47]. In the present work, the performance of carbon materials as noble metal supports in the gas-phase combustion of BTX and acetone is reviewed. The influence of the porosity, surface chemistry and hydrophobicity of the carbon support on the active phase dispersion and the catalytic activity were addressed and compared to metal oxide-based catalysts.

Table 1. Catalytic oxidation of benzene, toluene and xylenes (BTX) over noble metal catalysts supported on carbon materials.

\begin{tabular}{|c|c|c|c|c|c|}
\hline Catalyst & VOCs type & Gas mixture & VHSV $\left(h^{-1}\right)$ & ${ }^{*} T_{50}\left({ }^{\circ} \mathrm{C}\right)$ & Ref. \\
\hline $\mathrm{Pt} / \mathrm{AC}$ & Toluene & $\begin{array}{l}90 \mathrm{ppm} / \text { air mixture } \\
442 \mathrm{ppm} / \text { air mixture }\end{array}$ & $\begin{array}{l}22,200 \\
13,500\end{array}$ & $\sim 160$ & [47] \\
\hline $\mathrm{Pt} / \mathrm{AC}$ & $\begin{array}{l}\text { Benzene } \\
\text { Benzene } \\
\text { Toluene } \\
\text { Xylenes }\end{array}$ & $\begin{array}{l}640 \mathrm{ppm} / \text { air mixture } \\
2000 \mathrm{ppm} / \text { air mixture } \\
2000 \mathrm{ppm} / \text { air mixture } \\
2000 \mathrm{ppm} / \text { air mixture }\end{array}$ & 21,500 & $\begin{array}{r}130 \\
150 \\
\sim 165 \\
\sim 185 \\
\end{array}$ & [48] \\
\hline $\mathrm{Pt} / \mathrm{AC}$ & $\begin{array}{l}\text { Benzene } \\
\text { Toluene } \\
o \text {-Xylene }\end{array}$ & 1000 ppm/air mixture & 8000 & $\begin{array}{l}\sim 175 \\
\sim 195 \\
\sim 240\end{array}$ & [49] \\
\hline $\mathrm{Pd} / \mathrm{AC}$ & $\begin{array}{l}\text { Benzene } \\
\text { Toluene } \\
\text { Xylenes }\end{array}$ & 1000 ppm/air mixture & 19,000 & $\begin{array}{l}\sim 290 \\
\sim 290 \\
\sim 425\end{array}$ & {$[50]$} \\
\hline $\mathrm{Pd} / \mathrm{AC}$ & $o$-Xylene & $1500 \mathrm{ppm} /$ air mixture & 50,000 & $\sim 175$ & {$[51]$} \\
\hline $\mathrm{Pd} / \mathrm{AC}$-zeolite- $\mathrm{CeO}_{2}$ & $p$-Xylene & $\begin{array}{l}1000 \mathrm{ppm} / \text { air mixture } \\
3000 \mathrm{ppm} / \text { air mixture }\end{array}$ & 7000 & $\begin{array}{r}175 \\
\sim 180\end{array}$ & {$[52]$} \\
\hline $\begin{array}{l}\mathrm{Pt} / \mathrm{ACF} \\
\mathrm{Pd} / \mathrm{ACF}\end{array}$ & Toluene & $1200 \mathrm{ppm} / 10 \% \mathrm{O}_{2}$ & 15,000 & $\begin{array}{l}\sim 140 \\
\sim 145\end{array}$ & {$[53]$} \\
\hline Pt/MWCNT & $\begin{array}{l}\text { Benzene } \\
\text { Toluene } \\
o \text {-Xylene }\end{array}$ & $100 \mathrm{ppm} /$ air mixture & 75,000 & $\begin{array}{r}\sim 115 \\
110 \\
\sim 105 \\
\end{array}$ & {$[54]$} \\
\hline $\mathrm{Pt} / \mathrm{MWCNT}$ & Toluene & $400 \mathrm{ppm} / 6 \% \mathrm{O}_{2}$ & 156,000 & $\sim 140$ & {$[55]$} \\
\hline $\mathrm{Pt} / \mathrm{CA}$ & Toluene & 0.1 vol.\%/air mixture & - & $\sim 145$ & {$[56]$} \\
\hline
\end{tabular}

$* T_{50}=$ Light-off temperature for a 50\% BTX conversion; $\mathrm{AC}=$ activated carbon; $\mathrm{ACF}=$ activated carbon fiber; $\mathrm{CA}=$ carbon aerogel; $\mathrm{MWCNT}=$ multi-walled carbon nanotubes. 


\section{Results and Discussion}

\subsection{Supported Catalysts versus Doped Catalysts}

The employment of advanced carbon materials extends the ways to develop combustion catalysts by using different approaches and formats, such as powders, grains, pellets, films, coatings on different monolith or foam structures and so on (Figure 1). Supported catalysts are traditionally prepared by a deposition method (e.g., impregnation, chemical vapor deposition-CVD) on the corresponding carbon support, previously prepared. Some years ago, our research group has proposed the synthesis of metal-doped carbon aerogels and their direct application as catalysts. These metal-doped materials are prepared by solving the precursor metal-salt into a starting solution of organic precursors, which is decomposed during a thermal treatment performed over the organic polymeric aerogel or xerogel [57]. Thus, the metal is reduced during carbonization by the organic matrix and an additional pretreatment is not needed, in contrast of supported catalysts. The metals used for doping are also active along all synthesis steps of the material, i.e., polymerization, carbonization and/or activation. Interactions between organic-inorganic phases determine the distribution and dispersion of metals, sintering resistance, porosity, graphitization, formation of different active phases, etc. Therefore, new challenges are possible in catalysis because resulting metal particles are active in many catalyzed processes.

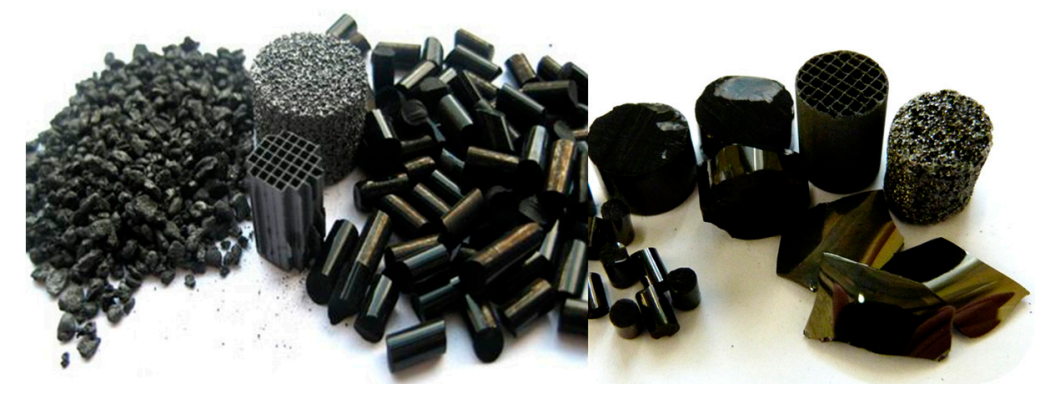

Figure 1. Carbon materials obtained in different formats: grains, powders, pellets, films and coatings on monolith and foam structures.

The issue of supported catalysts versus doped catalysts was studied with two Pt-catalyst series in the gas-phase combustion reaction of toluene [56]. The materials were prepared according the recipes regarded in Table 7 . The supported Pt catalysts ( $1 \mathrm{wt} . \% \mathrm{Pt}$ loading) were prepared by impregnation of

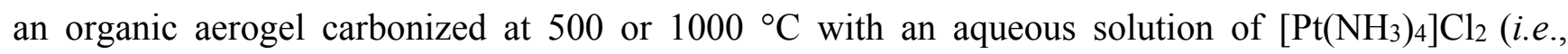
A500-Pt and A1000-Pt, respectively). The same precursor salt was used in the starting solution of Pt-doped catalysts (i.e., B500-Pt and B1000-Pt), a similar Pt content (around 1.1 wt.\%) than the impregnated catalysts being determined by thermogravimetric (TG) analysis after carbonization.

The thermal stability in air of carbon-based catalysts is an important parameter to study in reactions or processes requiring high and moderate temperatures. It depends not only on the previous thermal treatments of supports but also on the porous texture, active phase and metal dispersion. In general, the carbon supports are more stable when they are carbonized at higher temperature, while many metals may catalyze the carbon combustion reaction. For the Pt-catalysts series, the burn-off (B.O.) of the support was practically negligible below $300-400{ }^{\circ} \mathrm{C}$ (Figure 2), which was much higher than the temperature used to perform the catalytic oxidation of VOCs and thereby, the support gasification did not occur. 


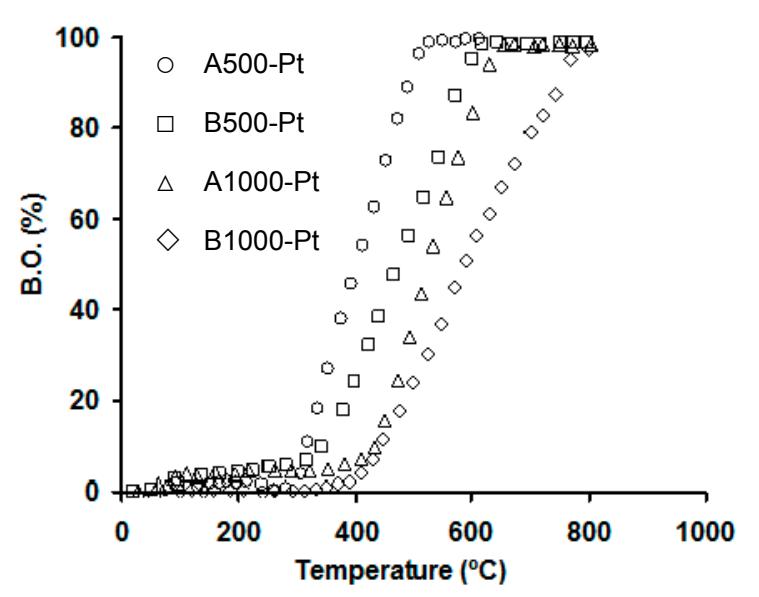

Figure 2. Percentage of burn-off (B.O.) in air against temperature for supported catalysts (A-samples) or doped (B-samples) carbonized at 500 and $1000{ }^{\circ} \mathrm{C}$. Figure reprinted with permission from [56]. Copyright 2004, Elsevier.

The toluene conversion to $\mathrm{CO}_{2}$ was obtained by using supported Pt-catalysts (A500-Pt) and Pt-doped catalysts (B500-Pt) on carbon aerogels (Figure 3). Only $\mathrm{CO}_{2}$ and water were found as reaction products, while partial oxidation products including $\mathrm{CO}$ and oxygenated organic compounds, were not detected by both gas chromatography (GC) or mass spectrometry (MS) techniques. The total toluene conversion was achieved below $200^{\circ} \mathrm{C}$ in both cases, although differences in the activity were observed to depend on several parameters, e.g., Pt-particle size. For catalysts prepared with supports at $500{ }^{\circ} \mathrm{C}$, Pt-particle size was $3.9 \mathrm{~nm}$ for $\mathrm{A} 500-\mathrm{Pt}$ after $\mathrm{H}_{2}$-pretreatment, while particles of $12 \mathrm{~nm}$ were obtained for B500-Pt. The higher activity of supported catalysts (A500-Pt) was related with a better Pt-dispersion and an easier accessibility of pollutants to Pt-particle sites. Moreover, in spite of the previously described advantages of metal-doped carbon gels, some metal particles were encapsulated by the organic matrix and thereby inactive in catalysis. In this context, both preparation methods present clear advantages and drawbacks, and the catalyst preparation (supported $v s$. doped) should be determined by the experimental conditions and the final application.

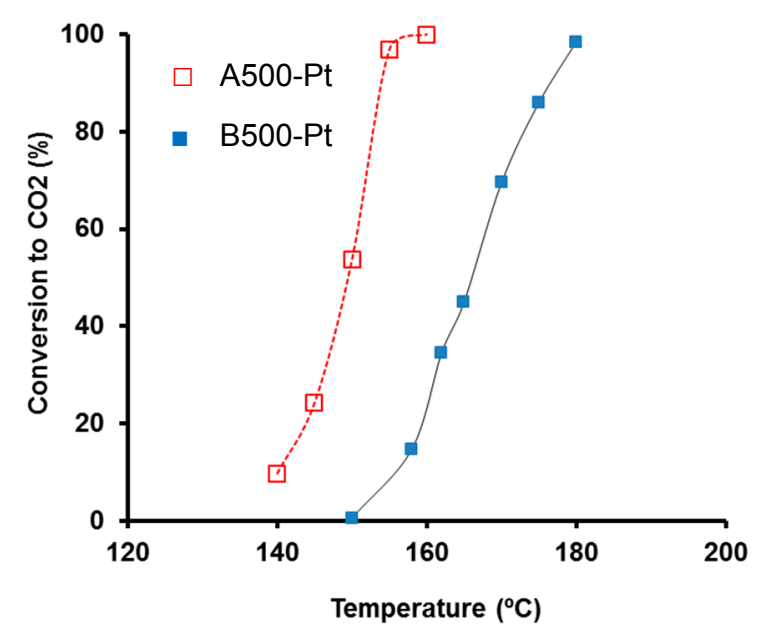

Figure 3. Catalytic performance obtained for supported $\mathrm{Pt}$ and Pt-doped catalysts on carbon aerogels in the toluene combustion ([toluene] $=0.45$ vol. $\%, Q=3.6 \mathrm{~L} \mathrm{~h}^{-1}, 0.10$ g $_{\text {catalyst}}$ ). Figure adapted with permission from [56]. Copyright 2004, Elsevier. 


\subsection{Influence of the Support Porosity}

Light-off curves for the A1000-Pt catalyst pre-treated in $\mathrm{H}_{2}$ were obtained under two different toluene concentrations in the feed stream (Figure 4). These results showed that the light-off curve was shifted to a lower temperature when the toluene concentration decreased from 0.45 to $0.10 \mathrm{vol} \%$, in agreement with VOCs oxidation obtained by other Pt catalysts [48,58]. In addition, the conversion to $\mathrm{CO}_{2}$ was lower than the total conversion of toluene when the catalyst was tested at low reaction temperatures, showing the participation of VOCs adsorption in the removal of pollutants under these experimental conditions, since partial oxidation products were not detected. Nevertheless, both conversions were matched when the reaction temperature increased due to a less favored adsorption of toluene and the enhancement of the combustion process.

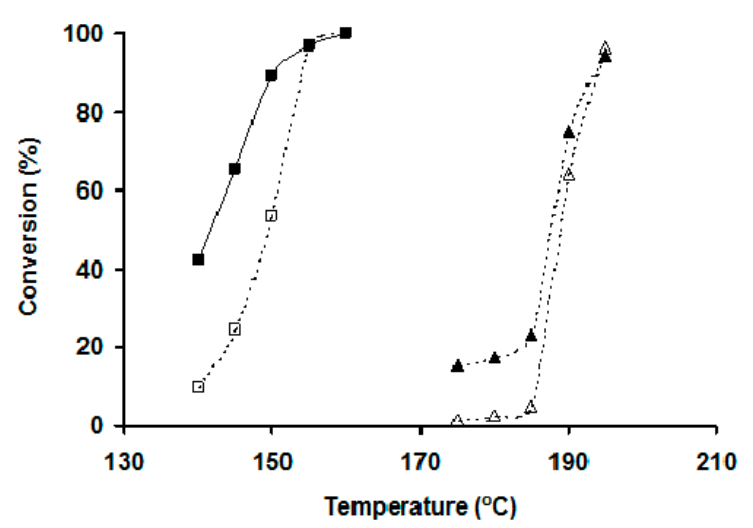

Figure 4. Light-off curves for A1000-Pt at two different toluene concentrations in the feeding gas: 0.10 vol.\% (squares) and 0.45 vol.\% (triangles). Open symbols: conversion to $\mathrm{CO}_{2}$. Closed symbols: conversion of toluene $\left(Q=3.6 \mathrm{~L} \mathrm{~h}^{-1}, 0.10\right.$ gcatalyst). Figure reprinted with permission from [56]. Copyright 2004, Elsevier.

VOCs' adsorption on the carbon support is an important key for the respective oxidation because it increases the surface density of adsorbed molecules in the metal-carbon interphase region and enhances the catalytic oxidation at low temperatures $[17,48]$. VOCs' adsorption is obviously controlled by the physical (porosity) and chemical (interactions) properties of carbon supports.

The macro-mesoporosity of carbon aerogels is commonly associated with the inter-particle voids, and thereby, can be controlled by modifying the synthesis conditions during the polymerization. On the other hand, the microporosity is generated by the release of gases during carbonization [57,59]. In this context, the pore size distribution (PSD) of the supports (carbon aerogels) was modulated by changing the polymerization catalyst (Table 7). Thus, when $\mathrm{Li}_{2} \mathrm{CO}_{3}$ was used as polymerization catalyst, the resulting carbon aerogel was mesoporous, whereas a macroporous support was produced with $\mathrm{Cs}_{2} \mathrm{CO}_{3}$. The analysis by mercury porosimetry indicated that both carbon aerogels had a homogenous and unimodal PSD with pore sizes of 25 and $96 \mathrm{~nm}$, respectively. The external and BET surface areas, as well as the meso- and macropore volumes are regarded in Table 2. 
Table 2. Textural characterization of the carbon aerogels.

\begin{tabular}{cccccc}
\hline Support & $* \boldsymbol{S}_{\text {BET }}\left(\mathbf{m}^{\mathbf{2}} \mathbf{g}^{-\mathbf{1}}\right)$ & $\boldsymbol{\rho}\left(\mathbf{g ~ c m}^{-\mathbf{3}}\right)$ & $\boldsymbol{V}_{\text {meso }}\left(\mathbf{c m}^{\mathbf{3}} \mathbf{g}^{-1}\right)$ & $\boldsymbol{V}_{\text {macro }}\left(\mathbf{c m}^{\mathbf{3}} \mathbf{g}^{-1}\right)$ & $\boldsymbol{S}_{\text {ext }}\left(\mathbf{m}^{\mathbf{2}} \mathbf{g}^{-\mathbf{1}}\right)$ \\
\hline ALi900 & 902 & 0.99 & 1.06 & 0.00 & 191 \\
ACs900 & 758 & 0.80 & 0.07 & 1.20 & 59 \\
\hline$* S_{\text {BET }}=$ BET surface area; $\rho=$ bulk density; $V_{\text {meso }}$ and $V_{\text {macro }}=$ meso- and macropore volume determined by \\
mercury porosimetry; S $_{\text {ext }}=$ surface area due to macropores and mainly mesopores.
\end{tabular}

The mesoporous and macroporous aerogels (ALi900 and ACs900) were used to prepare supported Pt-catalysts, which after $\mathrm{H}_{2}$-pretreatment at $300{ }^{\circ} \mathrm{C}$ showed a Pt-particle size $\left(\mathrm{d}_{\mathrm{Pt}}\right)$ around $1.5 \mathrm{~nm}$ regardless the support used. When the catalytic activity of both catalysts pretreated at $300{ }^{\circ} \mathrm{C}$ was analyzed in the combustion of benzene (Figure 5), the only parameter affecting on their activity was the porous texture, since the surface oxygen content, $\mathrm{pH}$ PZC (point of zero charge) and Pt-dispersion were similar. ALi900Pt was more active than ACs900Pt for the temperatures range studied, benzene being totally and selectively converted to $\mathrm{CO}_{2}$ at only $160{ }^{\circ} \mathrm{C}$. This larger catalytic activity of ALi900Pt is related with the role of mesoporosity and $\mathrm{S}_{\text {ext }}$ of the support, as previously indicated. In the mesoporous support, benzene molecules easily access to the porosity and are adsorbed throughout the large $\mathrm{S}_{\mathrm{ext}}$ containing a high concentration of Pt-particles. Thus, the high benzene concentration near to reactive Pt-Particles enhanced the benzene oxidation at low temperatures.

The role of the support porosity was also assessed by Pd-catalysts supported on honeycomb ceramic monoliths [60], in particular three different carbon-based monoliths and their catalytic performance was studied in the total gas-phase combustion of $m$-xylene. The first monolith (HPM) was a square channel cordierite modified with $\alpha-\mathrm{Al}_{2} \mathrm{O}_{3}$, on which a carbon layer was deposited (Figure $6 \mathrm{c}$ ). The other two monolithic supports (WA and WB) were carbon/ceramic composites with different porosity (Figure 6b). A cross-section detailed of the channels of a monolith coated with a $\gamma-\mathrm{Al}_{2} \mathrm{O}_{3}$ layer is also shown in Figure 6a for comparison.

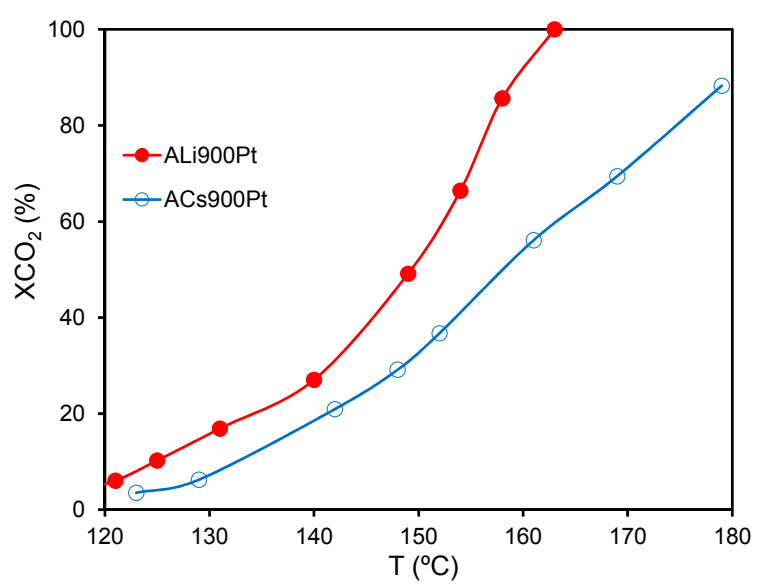

Figure 5. Influence of the macro-mesoporosity of supports on the benzene catalytic combustion ([benzene] $=1000 \mathrm{ppm}, Q=3.6 \mathrm{~L} \mathrm{~h}^{-1}, 0.10 \mathrm{~g}_{\text {catalyst}}$ ). Figure adapted with permission from [61]. Copyright 2010, Elsevier. 

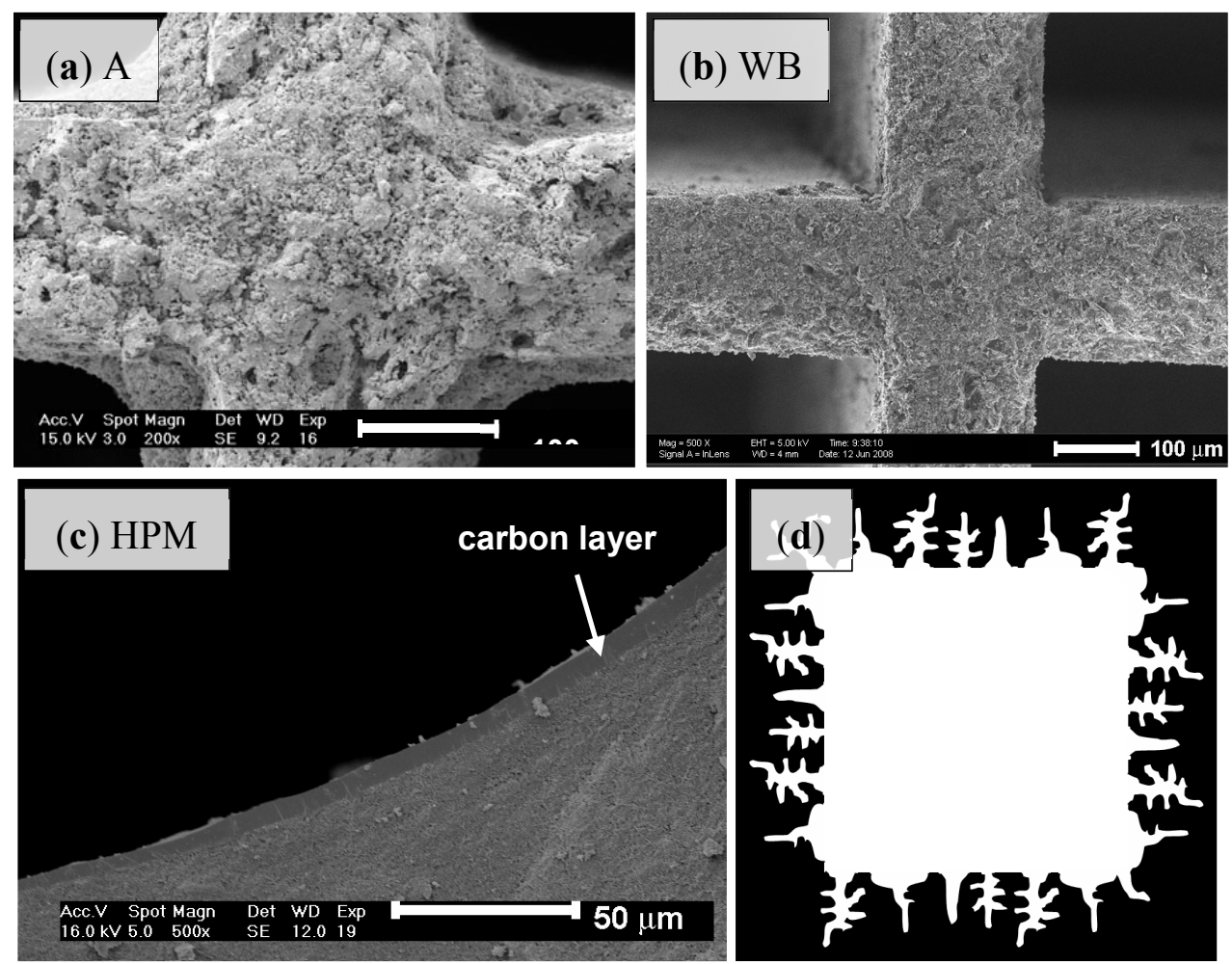

Figure 6. SEM micrographs of the monolith channels: details of (a) $\gamma-\mathrm{Al}_{2} \mathrm{O}_{3}$ layer; (b) carbon/ceramic composite and (c) carbon coating. (d) Model of the porosity developed for carbon-based monoliths. Figures reprinted with permission from [60,62,63]. Copyright 2008, 2009, Elsevier.

The textural properties of the carbon-based monoliths were analyzed (Table 3), different porosities being determined depending on the type of support used. In this context, the carbon layer in HPM presented only small micropores, since $S_{\mathrm{BET}}$ was much lower than $S_{\mathrm{CO} 2}$. Both WA and WB monoliths had a heterogeneous micropore size distribution (i.e., $S_{\mathrm{BET}}$ was higher than $S_{\mathrm{CO} 2}$ ), while WA presented only macropores and WB had meso- and macropores (Figure 6d) and consequently, a larger $S_{\text {ext. }}$

Table 3. Surface characteristics of the monolithic supports. Data in parenthesis are given per gram of carbon.

\begin{tabular}{cccccc}
\hline Monolith & $* \boldsymbol{S}_{\mathbf{C O} 2}\left(\mathbf{m}^{\mathbf{2}} \mathbf{g}^{-\mathbf{1}}\right)$ & $\boldsymbol{S}_{\text {BET }}\left(\mathbf{m}^{2} \mathbf{g}^{-\mathbf{1}}\right)$ & $\boldsymbol{S}_{\text {ext }}\left(\mathbf{m}^{\mathbf{2}} \mathbf{g}^{-\mathbf{1}}\right)$ & $\boldsymbol{V}_{\text {macro }}\left(\mathbf{c m}^{\mathbf{3}} \mathbf{g}^{-\mathbf{1}}\right)$ & $\boldsymbol{V}_{\text {meso }}\left(\mathbf{c m}^{\mathbf{3}} \mathbf{g}^{-\mathbf{1}}\right)$ \\
\hline WA & $329(947)$ & $474(1366)$ & $4(12)$ & $0.325(0.937)$ & 0 \\
WB & $242(782)$ & $460(1489)$ & $62(199)$ & $0.233(0.754)$ & $0.138(0.447)$ \\
HPM & $17(269)$ & $(2)$ & $(<1)$ & (n.d. $)$ & (n.d.) \\
\hline
\end{tabular}

* By application of Dubinin-Radushkevich equation to $\mathrm{CO}_{2}$ adsorption data; n.d. = not detected.

Pd-catalysts supported on the previous monoliths presented a comparable Pd loading with very similar Pd particle sizes (around 5-6 nm), although differences were found in their location. Thus, $\mathrm{Pd}$ was situated only in the macropores of the Pd/WA catalyst, while for Pd/WB the Pd was distributed throughout the mesoporous texture. In the case of Pd/HPM, Pd-particles were deposited on the 
external surface of the carbon layer, since the size of the metal particles avoided their deposition in the respective micropores.

The reaction rates of the monolithic catalysts were obtained for the gas-phase catalytic combustion of $m$-xylene (Figure 7). The total combustion of $m$-xylene was reached at $170{ }^{\circ} \mathrm{C}$ for $\mathrm{Pd} / \mathrm{WB}$, which was the most active catalyst, with a total selectivity to $\mathrm{CO}_{2}$ and $\mathrm{H}_{2} \mathrm{O}$. In addition, the catalytic performance was very different, the rate of the catalysts being varied as follows: $\mathrm{Pd} / \mathrm{HPM}<\mathrm{Pd} / \mathrm{WA}<\mathrm{Pd} / \mathrm{WB}$, i.e., in according to the external surface area of the corresponding support (Table 3). Therefore, the macropores and mainly mesopores, play an important role in this type of gas-phase reactions, improving the contact between Pd-particles and $m$-xylene molecules, in agreement with previous results for carbon aerogels supported catalysts.

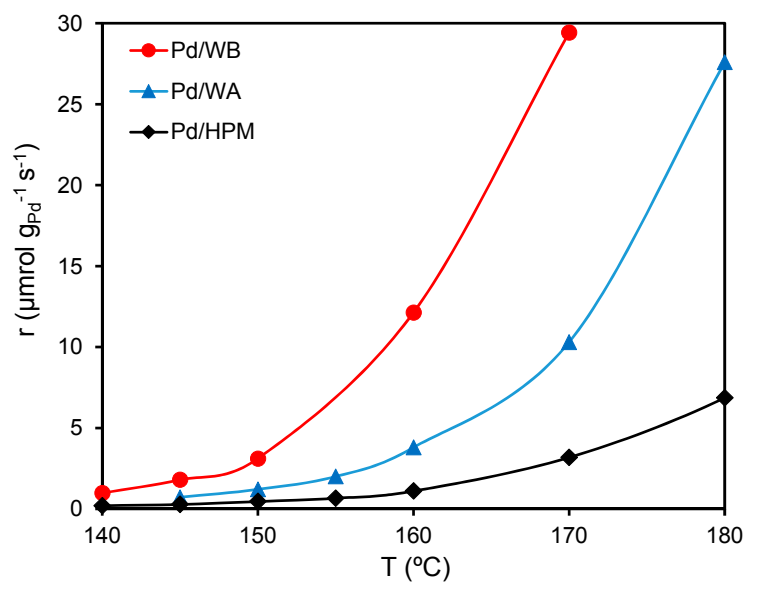

Figure 7. Catalytic performance of the monolithic catalysts normalized per gram of $\mathrm{Pd}$ in the $m$-xylene combustion $\left([m\right.$-xylene $]=0.10$ vol. $\%, Q=2000 \mathrm{~m}^{3}$ gas $\mathrm{h}^{-1} \mathrm{~m}^{-3}$ monolith $)$. Figure adapted with permission from [60]. Copyright 2008, Elsevier.

Since the carbon materials are highly porous solids, the preconcentration of VOCs in their surface by adsorption facilitates their combustion (as indicated), but also the synergy adsorbent/catalyst will have an important role. Therefore, the adsorptive behavior of this type of materials in the removal of VOCs will depend markedly on the operational conditions. In this context, the adsorption of different VOCs over carbon aerogel-based catalysts was studied by TG in dynamic mode (Figure 8) [59,64]. As expected, the adsorption capacity and the adsorption rate for A500-Pt decrease with higher temperatures (Figure 8a), since adsorption only takes place in progressively narrower pores and consequently, the adsorption capacity decreases. On the other hand, adsorption/desorption cycles for A500-Pt and A1000-Pt at constant temperature (Figure 8b) showed a comparable toluene adsorption rate for both aerogels regardless the catalyst and the carbonization temperature used, because the mean micropore sizes $\left(\mathrm{L}_{0}\right)$ were always around $0.57 \pm 0.03 \mathrm{~nm}$. However, the adsorption capacity for both samples was favored for the sample carbonized at higher temperature (A1000-Pt) due to a larger development of its microporosity, compared to A500-Pt. These results also pointed out that the toluene adsorption is reversible by thermal treatment of the corresponding support (Figure $8 b$ ). 


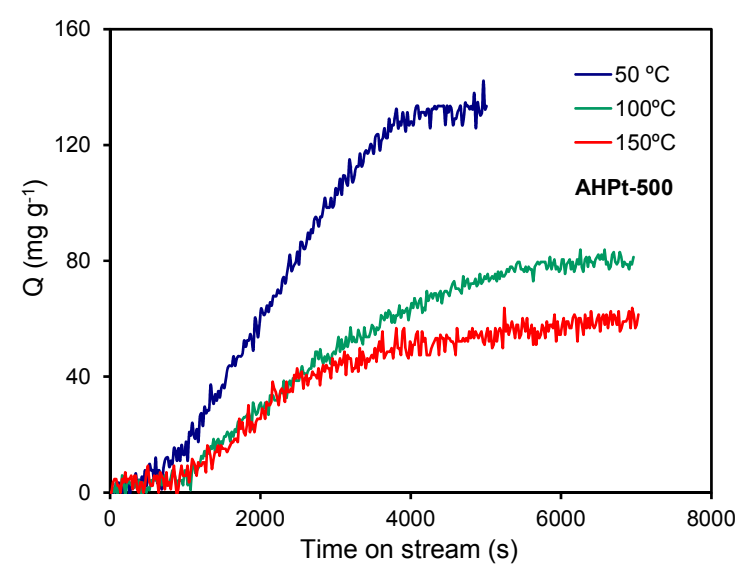

(a)

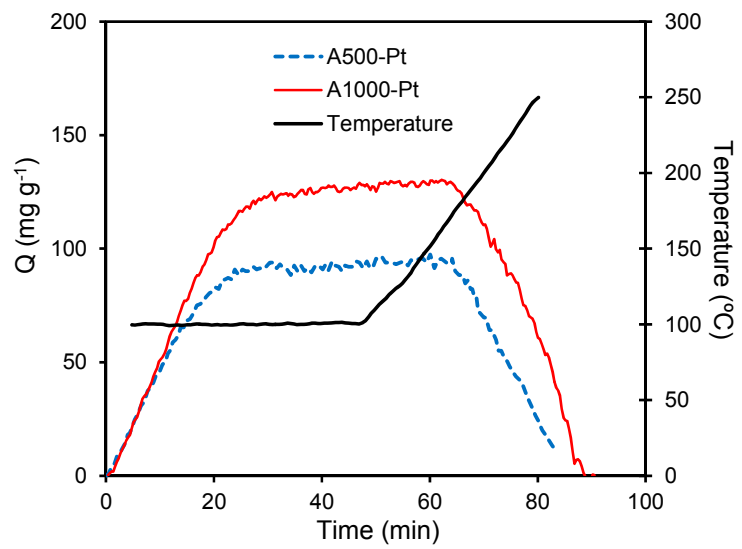

(b)

Figure 8. Dynamic toluene adsorption: (a) effect of the adsorption temperature and (b) effect of the carbonization temperature $\left(Q=3.6 \mathrm{~L} \mathrm{~h}^{-1}, 0.10 \mathrm{~g}_{\text {catalyst}}\right)$. Figures adapted with permission from [64]. Copyright 2011, Elsevier.

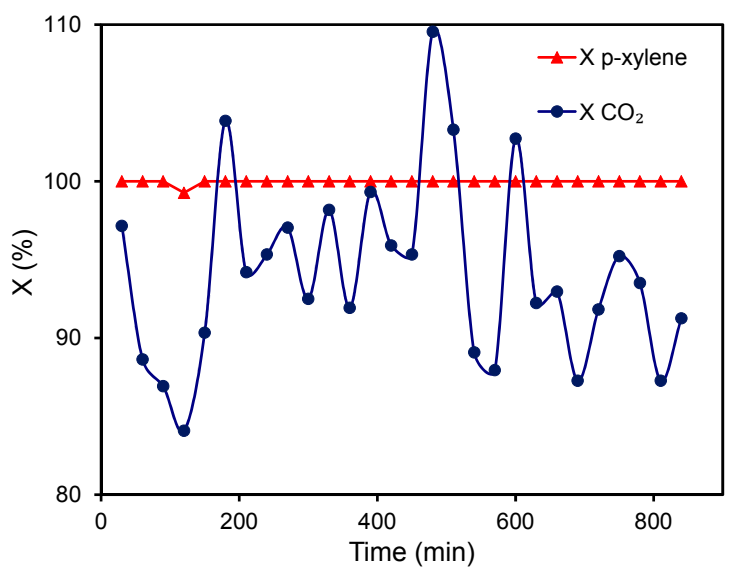

(a)

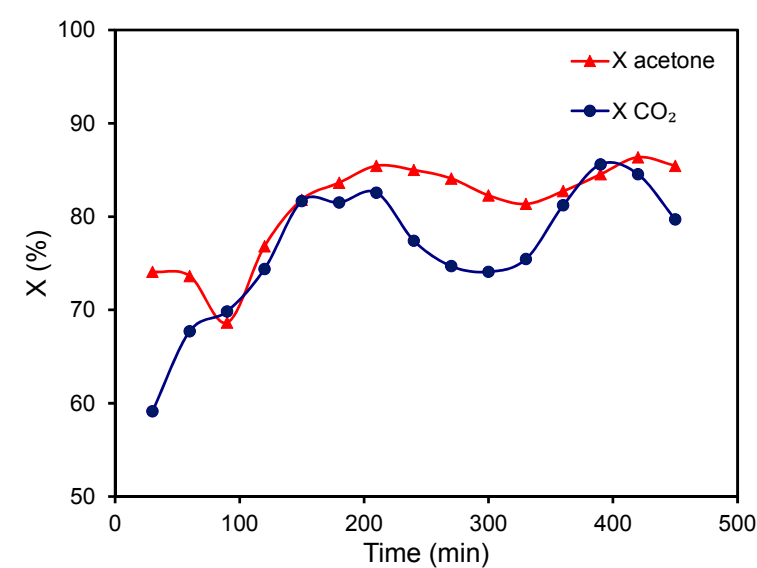

(b)

Figure 9. Catalytic stability of A500-Pt over the combustion of (a) $p$-xylene at $170{ }^{\circ} \mathrm{C}$ and (b) acetone at $210{ }^{\circ} \mathrm{C}\left([\mathrm{VOC}]=1500 \mathrm{ppm}, Q=3.6 \mathrm{~L} \mathrm{~h}^{-1}, 0.10 \mathrm{~g}_{\text {catalyst }}\right)$. Figures adapted with permission from [64]. Copyright 2011, Elsevier.

The catalytic performance of A500-Pt was assessed in the combustion of $p$-xylene at $170{ }^{\circ} \mathrm{C}$ and acetone at $210{ }^{\circ} \mathrm{C}$ (Figure 9a,b, respectively). The total conversion $\left(\mathrm{X}_{\mathrm{T}}\right)$ of $p$-xylene was reached and maintained at $170{ }^{\circ} \mathrm{C}$ over time, however the corresponding conversion to $\mathrm{CO}_{2}\left(\mathrm{X}_{\mathrm{CO} 2}\right)$ showed small positive and negative oscillations around 100\% (Figure 9a). For the acetone combustion (Figure 9b), the total conversion was lower than that obtained for $p$-xylene, i.e., acetone is less reactive than $p$-xylene. In addition, both $\mathrm{X}_{\mathrm{T}}$ and $\mathrm{X}_{\mathrm{CO} 2}$ curves showed large oscillations, in particular $\mathrm{X}_{\mathrm{CO} 2}$ under these experimental conditions. This oscillatory behavior was reported in the literature as a consequence of adsorbed VOCs or coke-precursor burning with Pt-catalysts supported on inorganic supports such as, zeolites or alumina [65]. However, the toluene adsorption was completely reversible for carbon aerogels with different porous textures as previously showed [59] and thereby, the VOCs interaction with the basic carbon surface should be weaker than that obtained with acidic inorganic supports. Thus, VOCs are only 
adsorbed and oxidized over carbon-based catalysts without any transformation and deposition of stable coke or coke precursor.

In summary, carbon-based catalysts present a versatile behavior, since they can behave as good adsorbents at low temperatures and as excellent combustion catalysts at high reaction temperatures. The temperature range depends obviously on material properties (e.g., porosity, surface chemistry, active phase and metal dispersion) and on VOCs nature. In this context, O'Malley and Hodnett [66] defined a reactivity pattern for different Pt-inorganic supports as follows: alcohols $>$ aromatics $>$ ketones $>$ carboxylic acids $>$ alkanes, according to the weakness of $\mathrm{C}-\mathrm{H}$ bonds.

The equilibrium between both adsorption and catalytic processes was studied by changing the weight of catalyst used $(0.10$ or $0.30 \mathrm{~g}$ of A1000-Pt), i.e., by varying the contact time, over the $m$-xylene combustion at $190{ }^{\circ} \mathrm{C}$ (Figure 10). When $0.10 \mathrm{~g}$ of catalyst was used, the $m$-xylene removal reached at the beginning of the reaction was only due to adsorption, since $\mathrm{X}_{\mathrm{CO} 2}$ was null. After saturation (at around $2 \mathrm{~h}$ on stream) $\mathrm{X}_{\mathrm{T}}$ becomes also very low, but both $\mathrm{X}_{\mathrm{T}}$ and $\mathrm{X}_{\mathrm{CO} 2}$ simultaneously increased over reaction time because the $m$-xylene removal by catalytic combustion increased for $17 \mathrm{~h}$ until total conversion. The enhanced catalytic activity can be also explained by the sintering of Pt particles, as previously reported [56]. By increasing the contact time (using $0.30 \mathrm{~g}$ of A1000-Pt), the removal of $m$-xylene was also total during the first $2 \mathrm{~h}$ but after saturation, the $\mathrm{X}_{\mathrm{T}}$ decay was smaller than that observed when $0.10 \mathrm{~g}$ of catalyst was used, because the $\mathrm{X}_{\mathrm{CO} 2}$ evolution was faster due to the combustion process improved by the presence of a larger amount of active sites. In this case, total removal of $m$-xylene to $\mathrm{CO}_{2}$ was reached after $7 \mathrm{~h}$, compared to $17 \mathrm{~h}$ obtained when $0.10 \mathrm{~g}$ of catalyst was used. Therefore, at this temperature the adsorption process occurs initially faster than the combustion reaction, although the catalytic removal of VOCs is progressively favored by the preconcentration on the catalyst surface and by the sintering of Pt-particles. The influence of this parameter will be deeply studied in the subsequent Section. Oscillations in both $\mathrm{X}_{\mathrm{T}}$ and $\mathrm{X}_{\mathrm{CO} 2}$ indicate the establishment of a continuous equilibrium between different adsorption/reaction cycles, while $\mathrm{X}_{\mathrm{CO} 2}$ values higher than $100 \%$ demonstrated the combustion of compounds previously adsorbed.

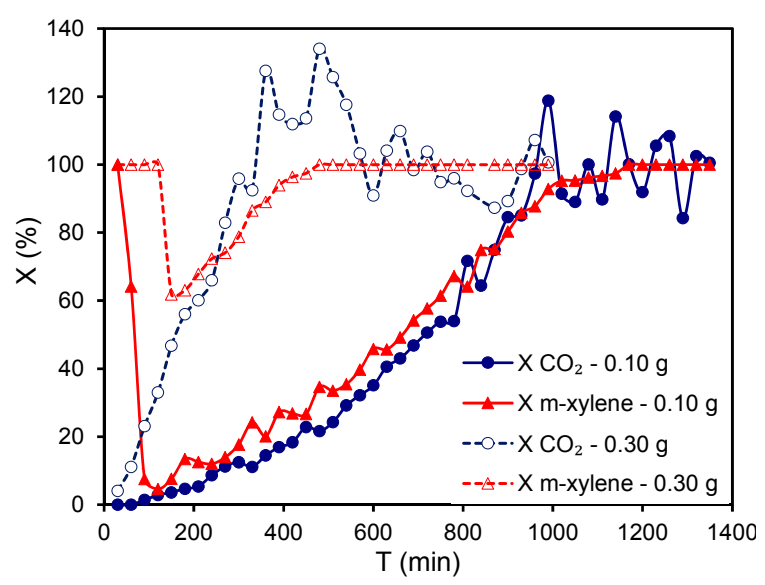

Figure 10. Influence of the contact time on the $m$-xylene combustion obtained for A1000-Pt at $190{ }^{\circ} \mathrm{C}\left([m\right.$-xylene $]=1500 \mathrm{ppm}, Q=3.6 \mathrm{~L} \mathrm{~h}^{-1}, 0.10$ or 0.30 gcatalyst $)$. Figure adapted with permission from [64]. Copyright 2011, Elsevier. 


\subsection{Influence of the Metal Particle Size}

The influence of this parameter on the catalytic performance in gas-phase combustion reactions has generated certain controversy. Some authors classify the combustion as a structure-sensitive reaction with the Pt particle size, having a detrimental effect on the conversion [56,67]. However, Tsou et al. [65] did not find any dependency on Pt-dispersion for the o-xylene combustion with Pt/HBEA zeolite. Therefore, these discrepancies suggest that the correlation between the Pt particle size and catalytic activity is influenced by the catalyst support selected.

For the sake of elucidating this issue, a Pt catalyst supported on a mesoporous carbon aerogel was pre-treated at different temperatures $\left(400,600\right.$ and $950{ }^{\circ} \mathrm{C}$ ) in He flow (i.e., APt400He, APt600He and APt950He, respectively) or at $400{ }^{\circ} \mathrm{C}$ in $\mathrm{H}_{2}$ flow (i.e., $\mathrm{APt} 400 \mathrm{H}_{2}$ ) [67]. The Pt particle size for the different catalysts was determined by $\mathrm{H}_{2}$ chemisorption $(\mathrm{dPt})$ and high resolution transmission electron microscopy (dPt-HRTEM), obtaining a well agreement between both techniques (Table 4). The He-pretreatments performed at 400 and $600{ }^{\circ} \mathrm{C}$ gave rise to small Pt particle sizes (between 2.3-2.8 nm). When the pre-treatment temperature increased up to $950{ }^{\circ} \mathrm{C}$, the catalyst with the largest Pt-particle size was obtained $(9.5 \mathrm{~nm})$. The $\mathrm{H}_{2}$-pretreatment at $400{ }^{\circ} \mathrm{C}$ led to a dPt-HRTEM value $(2.9 \mathrm{~nm})$ even slightly larger than that obtained after He-pre-treatment at $600{ }^{\circ} \mathrm{C}(2.4 \mathrm{~nm})$. Pt catalysts prepared with identical metal precursor and supported on other carbon materials [56,68] and even zeolites [69] also presented a loss of dispersion after $\mathrm{H}_{2}$-pretreatments. This behavior is due to the formation of an intermediate hydride, $\left[\mathrm{Pt}\left(\mathrm{NH}_{3}\right)_{2} \mathrm{H}_{2}\right]$, which is unstable and mobile, leading to an agglomeration of Pt-particles. He-pretreatments give rise to a gradual decomposition of the amino complex along two intermediate reactions: (1) reaction takes place between 275 and $315^{\circ} \mathrm{C}$ and (2) reaction between 315 and $370{ }^{\circ} \mathrm{C}$ [70].

$$
\begin{gathered}
{\left[\mathrm{Pt}\left(\mathrm{NH}_{3}\right)_{4}\right] \mathrm{Cl}_{2} \rightarrow\left[\mathrm{Pt}\left(\mathrm{NH}_{3}\right)_{2} \mathrm{Cl}_{2}\right]+2 \mathrm{NH}_{3}} \\
3\left[\mathrm{Pt}\left(\mathrm{NH}_{3}\right)_{2} \mathrm{Cl}_{2}\right] \rightarrow 3 \mathrm{Pt}+\mathrm{N}_{2}+4 \mathrm{NH}_{3}+6 \mathrm{HCl}
\end{gathered}
$$

Table 4. Hydrogen uptake ( $\left.\mathrm{Q}_{\mathrm{t}}\right)$, dispersion (D) and Pt particle size of supported catalysts.

\begin{tabular}{ccccc}
\hline Catalyst & ${ }^{*} \mathbf{Q}_{\mathbf{t}}\left(\boldsymbol{\mu} \mathbf{m o l} \mathbf{H}_{\mathbf{2}} \mathbf{g}^{-\mathbf{1}}\right)$ & ${ }^{\mathbf{D}} \mathbf{( \% )}$ & ${ }^{\mathbf{*}} \mathbf{d}_{\mathbf{P t}}(\mathbf{n m})$ & $\mathbf{d}_{\text {Pt-HRTEM }}(\mathbf{n m})$ \\
\hline APt400He & 12.0 & 46.8 & 2.3 & - \\
$\mathrm{APt} 600 \mathrm{He}$ & 10.0 & 39.2 & 2.8 & 2.4 \\
$\mathrm{APt} 950 \mathrm{He}$ & 2.9 & 11.3 & 9.5 & 6.6 \\
$\mathrm{APt} 400 \mathrm{H}_{2}$ & - & - & - & 2.9 \\
\hline
\end{tabular}

* Data obtained by $\mathrm{H}_{2}$ chemisorption at $25^{\circ} \mathrm{C}$.

The pre-treated catalysts with different Pt particle sizes were tested in the gas-phase $o$-xylene combustion (Figure 11). The absence of $\mathrm{CO}_{2}$ converted $\left(\mathrm{X}_{\mathrm{CO} 2}\right.$, Figure $11 \mathrm{~b}$ ) and the total $o$-xylene

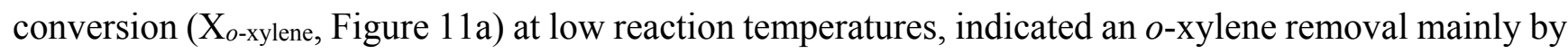
adsorption. The light-off curves shift to lower temperatures with increasing Pt particle size (Figure 11), APt950He and APt400He being the most and least active catalysts, respectively. Therefore, these results suggest that gas-phase $o$-xylene combustion over these Pt-catalysts is a structure-sensitive reaction. 

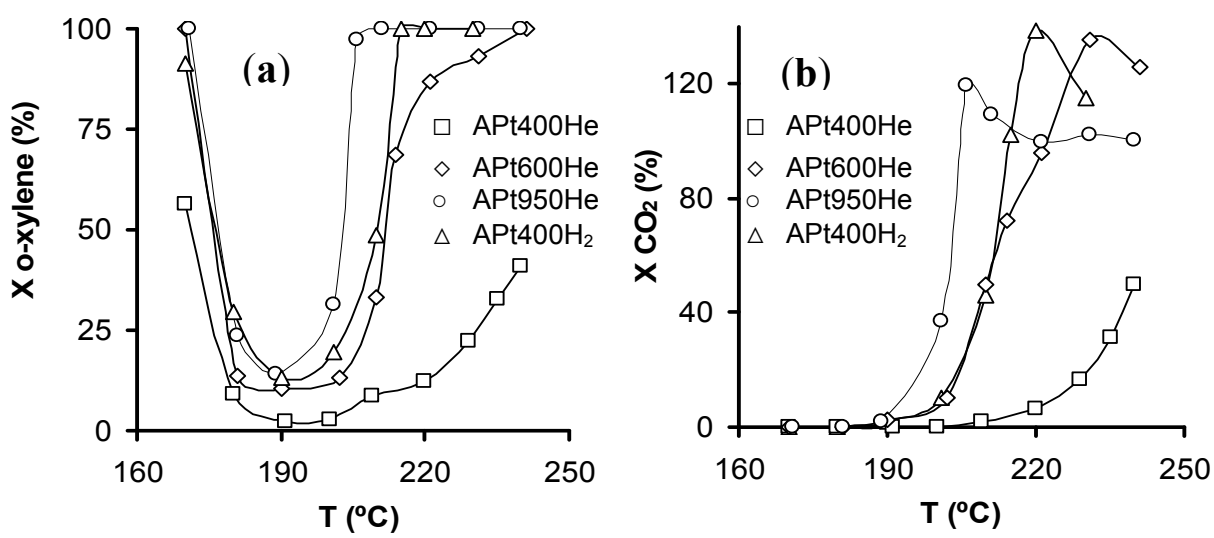

Figure 11. Light-off curves for the supported Pt catalysts: (a) conversion of $o$-xylene and (b) conversion to $\mathrm{CO}_{2}\left([o\right.$-xylene $]=0.10 \mathrm{vol} . \%, Q=3.6 \mathrm{~L} \mathrm{~h}^{-1}, 0.10$ g catalyst $)$. Figures reprinted with permission from [67]. Copyright 2005, Elsevier.

Furthermore, the catalyst activation during the reaction by sintering (Figure 10) was also reported by other authors $[71,72]$. This behavior seems to be markedly affected by the initial metal particle size of the catalyst. In this context, the $\mathrm{CO}_{2}$ formation as a function of reaction time was monitored at $190{ }^{\circ} \mathrm{C}$ (Figure 12), in which no $o$-xylene combustion to $\mathrm{CO}_{2}$ was detected (Figure 11b). As previously mentioned, Pt catalysts are activated after a certain period of time under these experimental conditions and the conversion to $\mathrm{CO}_{2}$ increases (Figure 12). However, this behavior was not observed with APt $400 \mathrm{He}$, which is the catalyst with the highest Pt-dispersion.

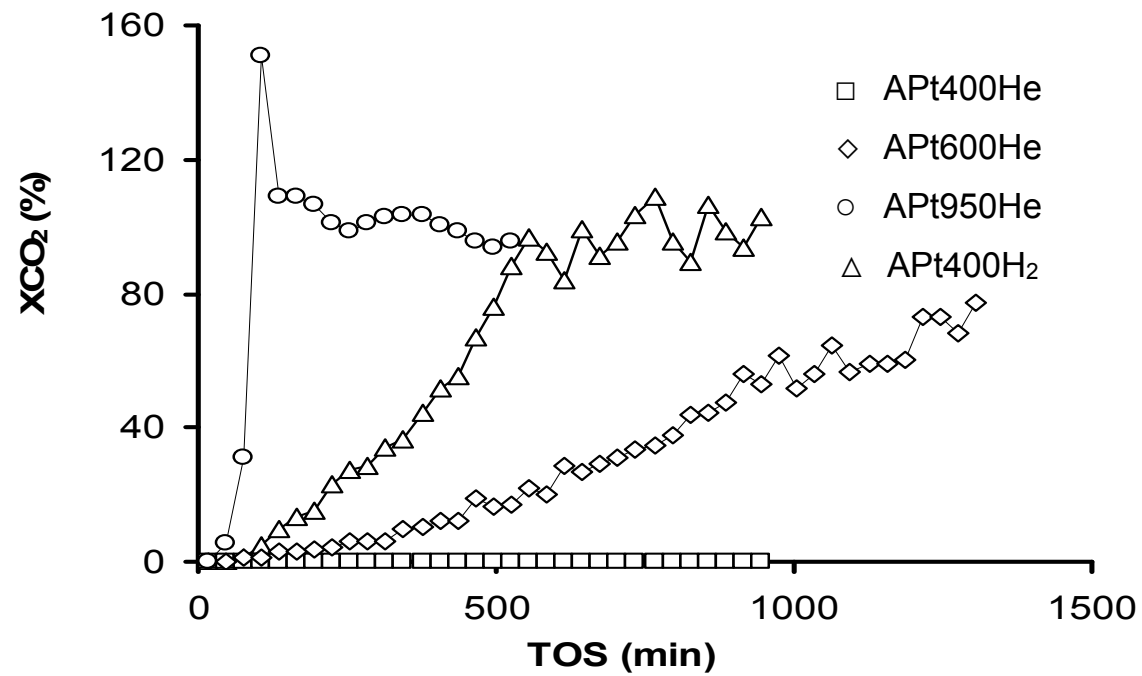

Figure 12. Conversion of $o$-xylene to $\mathrm{CO}_{2}$ obtained at $190{ }^{\circ} \mathrm{C}$ in function of time on stream (TOS) $\left([o\right.$-xylene $]=0.10$ vol. $\left.\%, Q=3.6 \mathrm{~L} \mathrm{~h}^{-1}, 0.10 \mathrm{~g}_{\text {catalyst }}\right)$. Figures reprinted with permission from [67]. Copyright 2005, Elsevier.

The catalyst activation during reaction time was also pointed out with two consecutive light-off curves [67]. Light-off curves in the second run were shifted to a lower temperature compared to those obtained with the first run. The difference between both curves, $\Delta \mathrm{T}$, is a measurement of the activation degree of the catalyst after the first combustion run. These results showed that the most activated catalyst was APt950He, which was also the most active catalyst during the $o$-xylene combustion. 


\subsection{Influence of the Support Surface Chemistry}

If there is a highlighted property of the carbon materials, it is their easily tuneable surface chemistry. Its influence on the catalytic performance in gas-phase VOCs combustion was pointed out by using supported Pt-catalysts on oxidized carbon aerogels. Thus, the mesoporous and macroporous carbon aerogel (ALi900 and ACs900, respectively) were oxidized with different agents: hydrogen peroxide (9.8 $\mathrm{M} \mathrm{H}_{2} \mathrm{O}_{2}-\mathrm{AX} 900 \mathrm{H}$ samples) and ammonium peroxydisulfate $\left(\left(\mathrm{NH}_{4}\right)_{2} \mathrm{~S}_{2} \mathrm{O}_{8}-\mathrm{AX} 900 \mathrm{~S}\right.$ samples) [73], before being used as Pt catalyst supports.

The oxidation treatments performed on the carbon aerogels did not modify significantly their porosity, but their surface chemistry changed from basic to acid as oxygen content increased (Table 5). The porosity preservation allowed us to study accurately the influence of the surface chemistry on the $\mathrm{Pt}$ particle size of the corresponding catalysts, which increased for those prepared on oxidized supports (e.g., 1.6 and $2.4 \mathrm{~nm}$ for ALi900 and ALi900S, respectively). This loss of Pt-dispersion was more notorious when the amount of oxygen-containing surface groups increased and, in particular, for macroporous oxidized supports. In this context, the Pt particle size increased from 2.4 to $3.9 \mathrm{~nm}$ for ALi900SPt pre-treated at 300 and $450{ }^{\circ} \mathrm{C}$, respectively, while a more evident increase was observed for ACs900SPt pre-treated under the same conditions, i.e., dPt increased from 3.4 to $6.0 \mathrm{~nm}$, respectively. Therefore, the increase of oxygen content in the supports favors the Pt sintering, while large external surface areas (mesoporous supports) prevent in certain extent the sintering, which is more marked with high pre-treatment temperatures.

Table 5. Amounts of $\mathrm{CO}$ and $\mathrm{CO}_{2}$ evolved up to $1000{ }^{\circ} \mathrm{C}$ and oxygen content (OTPD) from TPD experiments, measurements of $\mathrm{pH}$ PZC and mean Pt particle size for the derivatives $\mathrm{Pt} / \mathrm{C}$.

\begin{tabular}{cccccc}
\hline Support/catalyst & $\mathbf{C O}\left(\boldsymbol{\mu \mathbf { m o l }} \mathbf{g}^{-\mathbf{1}}\right)$ & $\mathbf{C O}_{\mathbf{2}}\left(\boldsymbol{\mu \mathbf { m o l ~ g }} \mathbf{g}^{\mathbf{- 1}}\right)$ & $\mathbf{O}_{\mathbf{T P D}}(\mathbf{\%})$ & $\mathbf{p H} \mathbf{H Z C}_{\mathbf{P C}}$ & ${ }^{*} \boldsymbol{d}_{\mathbf{P t}}(\mathbf{n m})$ \\
\hline ALi900 & 420 & 61 & 0.9 & 10.22 & 1.6 \\
ALi900H & 1110 & 335 & 2.9 & 4.94 & 2.0 \\
ALi900S & 2846 & 1621 & 9.7 & 3.16 & $2.4(3.9)$ \\
ACs900 & 534 & 59 & 1.0 & 10.28 & 1.5 \\
ACs900H & 832 & 364 & 2.5 & 6.89 & 1.8 \\
ACs900S & 2651 & 1522 & 9.1 & 3.85 & $3.4(6.0)$ \\
\hline
\end{tabular}

* Catalysts characterized after a $\mathrm{H}_{2}$-tretreatmen at $300{ }^{\circ} \mathrm{C}$ or $450{ }^{\circ} \mathrm{C}$ (data included in brackets).

The catalytic activity of the supported Pt catalysts was determined in the gas-phase combustion of benzene, studying the correlation with the surface chemistry once the porosity was comparable after oxidation treatments. In general, the employment of oxidized supports have two consequences: (i) a decrease of the hydrophobic character with the oxygen content of the support [74], since the oxygen-containing surface groups (called as primary centers) may interact with water molecules by hydrogen bonds; and (ii) a decrease of Pt-dispersion (as indicated). The loss of support hydrophobicity has a detrimental effect on the performance of the catalyst, because the re-adsorption of water generated during the reaction can block the active sites, namely at low reaction temperatures. Nevertheless, when the catalytic behavior for each series is analyzed, the conversion of benzene to $\mathrm{CO}_{2}$ increased with the order: un-oxidized $<\mathrm{H}$-treated $<\mathrm{S}$-treated supports (Figure 13). 

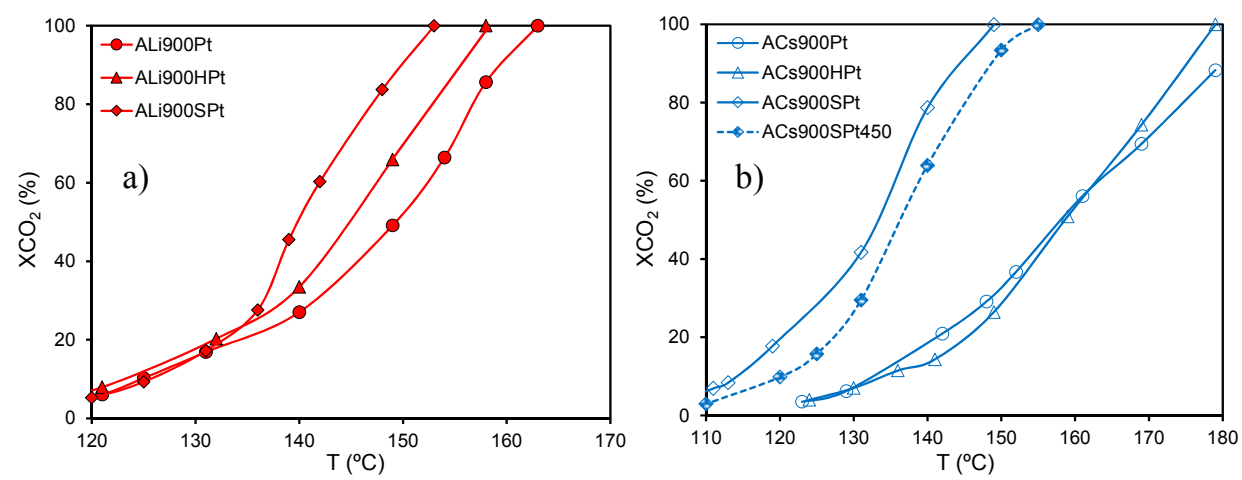

Figure 13. Light-off curves obtained in the benzene combustion for Pt catalysts supported on (a) mesoporous and (b) macroporous carbon aerogels ([benzene] $=1000 \mathrm{ppm}, Q=3.6 \mathrm{~L} \mathrm{~h}^{-1}$, $\left.0.10 \mathrm{~g}_{\text {catalyst}}\right)$. Figures adapted with permission from [61]. Copyright 2010, Elsevier.

As previously demonstrated, VOCs combustion with $\mathrm{Pt} / \mathrm{C}$ catalysts is a sensitive-structure reaction, in which Pt-dispersion would be the main parameter controlling the catalytic activity [67]. The hydrophilic character increases therefore after oxidation, producing a weak effect on the catalytic performance of oxidation catalysts supported on carbon materials. Therefore, the possible water re-adsorption favored by the increased hydrophilicity of the oxidized support is clearly compensated by the increase of activity induced by large Pt particles formed.

\subsection{Carbon versus Inorganic Supports: The Influence of the Hydrophobicity}

In order to clarify the influence of hydrophobicity of supports, this study was carried out by analyzing the catalytic activity of Pd and Pt catalysts supported on both carbon and inorganic supports, looking for a deeper hydrophobicity difference taking into account that changes in the hydrophobicity of oxidized carbon aerogels did not seem to influence significantly on the catalytic activity. In this context, two types of coatings were developed on a cordierite monolithic substrate. The first one was formed by a $\gamma-\mathrm{Al}_{2} \mathrm{O}_{3}$ layer (A monolith) and the another contained $3.3 \mathrm{wt} . \%$ of carbon nanofibers (ACNF monolith) grown in situ on the A monolith [63].

The corresponding $\gamma-\mathrm{Al}_{2} \mathrm{O}_{3}$ and $\mathrm{CNF}$ layers were thin, homogeneous and well-adhered on the cordierite substrate (Figure 14a). The CNFs layer was developed avoiding the formation of cracks and other defects on the cordierite monolith. Figure $6 \mathrm{a}$ and Figure $14 \mathrm{~b}$ show views of A and ACNF monolith channels, respectively, with different topologies being observed for each monolith. Some individual CNFs can be clearly observed through the monolith surface (Figure 14c). The different morphology obviously influenced on the textural properties of the monolithic supports. Thus, $S_{\text {BET }}$ significantly increased with the CNF coating compared to A monolith (Table 6). The analysis of the macro- and mesoporosity indicated that both samples are mainly macroporoses, the macropore volume in ACNF being larger than in A (i.e., 0.157 and $0.134 \mathrm{~cm}^{3} \mathrm{~g}^{-1}$, respectively) and the macropores being narrower after the CNF coating. 


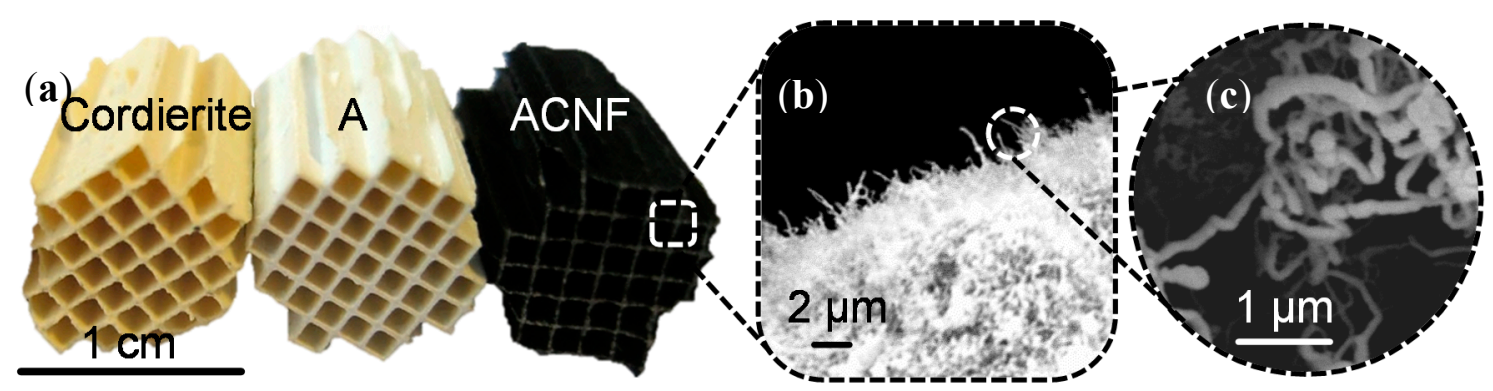

Figure 14. (a) Photograph of both $\gamma-\mathrm{Al}_{2} \mathrm{O}_{3}$ and CNF coatings on a cordierite monolith. SEM micrographs of the ACNF monolith: (b) cross-section of a monolith channel and (c) detail of CNF grown in situ.

Table 6. Textural characteristics of the monolithic supports.

\begin{tabular}{ccccc}
\hline Monolith & ${ }^{*} \boldsymbol{S}_{\text {BET }}\left(\mathbf{m}^{\mathbf{2}} \mathbf{g}^{-\mathbf{1}}\right)$ & $\boldsymbol{V}_{\text {macro }}\left(\mathbf{c m}^{\mathbf{3}} \mathbf{g}^{-\mathbf{1}}\right)$ & $\boldsymbol{V}_{\text {meso }}\left(\mathbf{c m}^{3} \mathbf{g}^{-\mathbf{1}}\right)$ & $*+{ }^{*}$ Enthalpy $\left(\mathbf{J ~ g}^{-\mathbf{1}}\right)$ \\
\hline A & 164 & 0.134 & 0.027 & -138.2 \\
ACNF & 371 & 0.157 & 0.028 & -103.8 \\
\hline
\end{tabular}

* Data given per gram of total coating material; $\uparrow$ By immersion calorimetry in water.
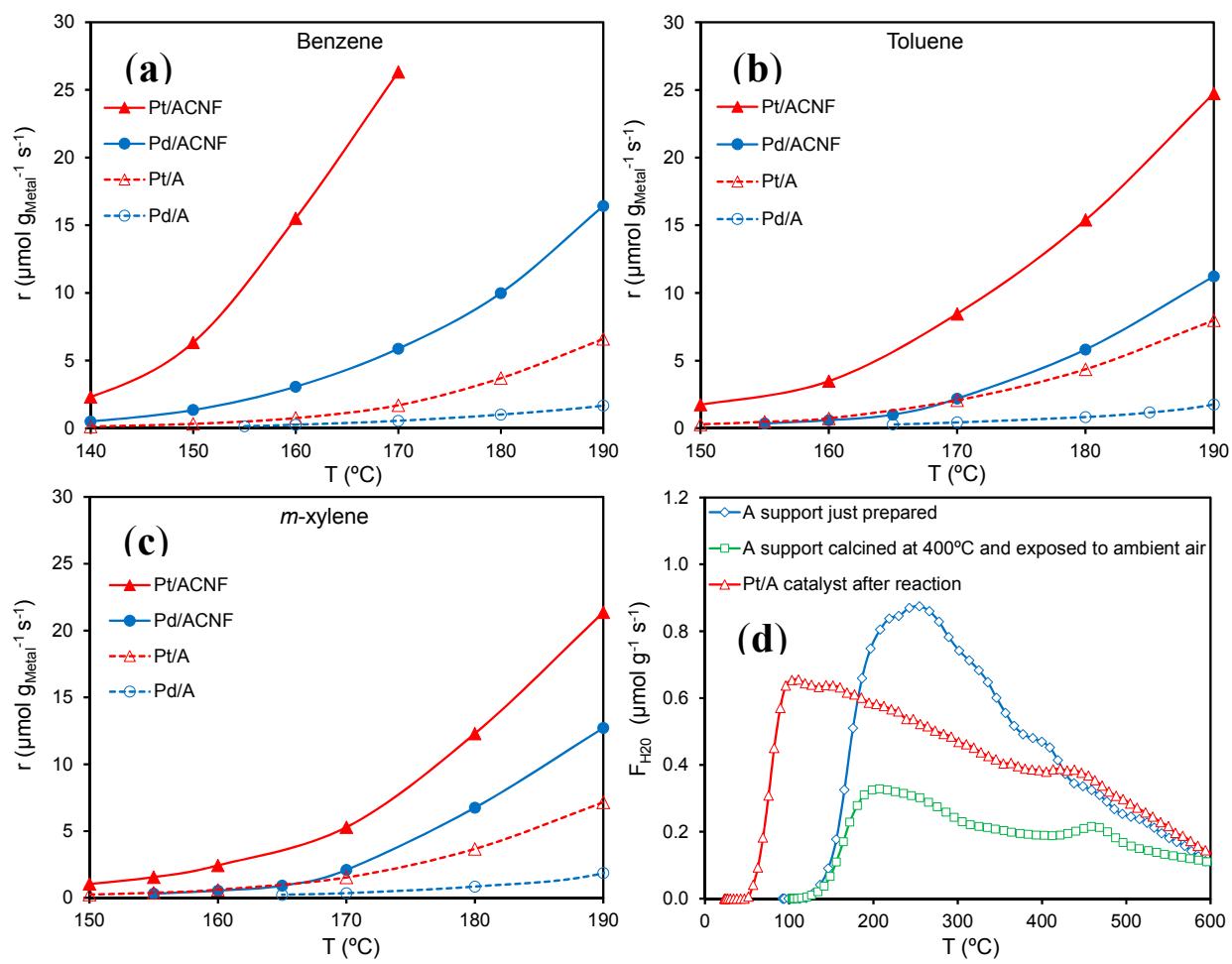

Figure 15. Catalytic activity of the catalysts (normalized per gram of $\mathrm{Pt}$ or $\mathrm{Pd}$ ) as a function of the reaction temperature: (a) combustion of benzene, (b) combustion of toluene and (c) combustion of $m$-xylene. (d) Water desorption profiles obtained by TPD. Figures adapted with permission from [63]. Copyright 2006, Elsevier.

Pt and Pd catalysts were prepared on both A and ACNF monoliths by the impregnation method and their catalytic activity was studied in the gas-phase combustion of benzene, toluene and m-xylene (Figure 15a-c, respectively). The conversion of the different VOCs tested, followed the sequence: 
$\mathrm{X}_{\text {benzene }}>\mathrm{X}_{\text {toluene }}>\mathrm{X}_{m \text {-xylene }}$ regardless the active phase and type of support used. In addition, Pt catalysts were more active than corresponding Pd-catalysts regardless the type of aromatic compound and support employed, the most active catalysts being always those supported on CNF coated monoliths. Furthermore, catalysts supported on A monoliths seem to burn equally any BTX, while those supported on ACNF showed preference to burn benzene better than toluene or $m$-xylene (Figure $15 \mathrm{a}-\mathrm{c}$ ), namely the $\mathrm{Pt} / \mathrm{ACNF}$ catalyst.

A possible explanation of these results was deduced by determining the adsorptive capacity of water for the A support and the Pt/A catalyst. The water desorption profiles obtained by TPD (Figure 15d) indicated that the A support (after calcined at $400{ }^{\circ} \mathrm{C}$ and exposed to ambient air at room temperature for a month), is able to reincorporate important amounts of water (like water itself or like hydroxyl groups by reaction with the $\mathrm{Al}$ atoms). Since the catalysts were pre-treated in $\mathrm{H}_{2}$ flow at $300{ }^{\circ} \mathrm{C}$ before being used in BTX combustions, water should not appear below $300{ }^{\circ} \mathrm{C}$ during the TPD experiment. However, a large amount of water was evolved, which should have been produced during the combustion. Therefore, the water adsorption of the alumina phase could produce a decrease on the activity of the corresponding supported catalysts. These results are in agreement with the lower water immersion enthalpy (Table 6) obtained for ACNF, which corroborates its large hydrophobic character. As a summary, the support hydrophobicity allowed enhancing the activity of supported Pt or Pd catalysts in the gas-phase combustion of BTX.

\section{Experimental Section}

\subsection{Preparation of Pt Catalysts Supported on Carbon Aerogels}

Organic aerogels were synthesized by polymerization of resorcinol (R) with formaldehyde (F) in an aqueous solution (W) containing a polymerization catalyst $(\mathrm{C})$ following the methodology suggested by Pekala et al. [14]. After curing and supercritical drying with $\mathrm{CO}_{2}$, the organic RF aerogels were carbonized in $\mathrm{N}_{2}$ flow at 500 or $900{ }^{\circ} \mathrm{C}$ yielding to the corresponding carbon aerogels, which were used as catalyst supports. Table 7 summarizes the recipe and the polymerization catalyst used: alkali carbonate $\left(\mathrm{Li}_{2} \mathrm{CO}_{3}, \mathrm{Na}_{2} \mathrm{CO}_{3}\right.$ and $\left.\mathrm{Cs}_{2} \mathrm{CO}_{3}\right)$ [75] or tetraammine platinum (II) chloride $\left(\left[\mathrm{Pt}\left(\mathrm{NH}_{3}\right)_{4}\right] \mathrm{Cl}_{2}\right)$ [56]. The supports will be referred to the text by indicating the support name (i.e., A, ALi, ACs or B) and the carbonization temperature $\left(500\right.$ or $\left.900{ }^{\circ} \mathrm{C}\right)$.

Table 7. Recipes used in the preparation of organic aerogels.

\begin{tabular}{ccccc}
\hline Support & $\mathbf{R} / \mathbf{F}$ & $\mathbf{R} / \mathbf{W}$ & $\mathbf{R} / \mathbf{C}$ & $\mathbf{C}$ \\
\hline $\mathrm{A}$ & 0.5 & 0.13 & 800 & $\mathrm{Na}_{2} \mathrm{CO}_{3}$ \\
$\mathrm{ALi}$ & 0.5 & 0.07 & 300 & $\mathrm{Li}_{2} \mathrm{CO}_{3}$ \\
$\mathrm{ACs}$ & 0.5 & 0.07 & 300 & $\mathrm{Cs}_{2} \mathrm{CO}_{3}$ \\
$\mathrm{~B}$ & 0.5 & 0.13 & 800 & $\left.\left[\mathrm{Pt}^{2} \mathrm{NH}_{3}\right)_{4}\right] \mathrm{Cl}_{2}$ \\
\hline
\end{tabular}

Two carbon aerogels (ALi900 and ACs900) were oxidized with different agents: (i) concentrated hydrogen peroxide $\left(\mathrm{H}_{2} \mathrm{O}_{2}, 9.8 \mathrm{M}\right)$ and (ii) a saturated solution of ammonium peroxydisulfate $\left(\left(\mathrm{NH}_{4}\right)_{2} \mathrm{~S}_{2} \mathrm{O}_{8}\right)$ in sulphuric acid $\left(\mathrm{H}_{2} \mathrm{SO}_{4}, 1 \mathrm{M}\right)$ [73]. The oxidation treatments were carried out for $48 \mathrm{~h}$ at an ambient temperature. Afterwards, the materials were washed with distilled water and dried at $120{ }^{\circ} \mathrm{C}$ 
for $24 \mathrm{~h}$. The supports oxidized with $\mathrm{H}_{2} \mathrm{O}_{2}$ and $\left(\mathrm{NH}_{4}\right)_{2} \mathrm{~S}_{2} \mathrm{O} 8$ will be labelled by adding " $\mathrm{H}$ " or "S" to the support name, respectively.

Supported Pt catalysts (1 wt.\%) were prepared by the incipient wetness impregnation method using an aqueous solution containing $\left[\mathrm{Pt}\left(\mathrm{NH}_{3}\right)_{4}\right]\left(\mathrm{NO}_{3}\right)_{2}$ or $\left[\mathrm{Pt}\left(\mathrm{NH}_{3}\right)_{4}\right] \mathrm{Cl}_{2}$ as metal precursor salts. The Pt-doped catalyst (B support) already included the active phase and thereby, no additional $\mathrm{Pt}$ was added. Prior to characterization or reaction, the catalysts were reduced in $\mathrm{H}_{2}$ or He flow at different temperatures (300, 400,600 or $950{ }^{\circ} \mathrm{C}$ ) for $3 \mathrm{~h}$. In determined studies (e.g., in the influence of Pt particle size), the reducing agent and temperature used will be also referred to the catalyst name.

\subsection{Preparation of Pt Catalysts Supported on Carbon-Based Monoliths}

For the HPM monolith, an $\alpha-\mathrm{Al}_{2} \mathrm{O}_{3}$ layer was applied on cordierite monolithic substrates (supplied by Corning Inc.) by dip-coating method, in order to block the cordierite macroporosity, to prevent deposition of catalytic material in the substrate walls and to round the channel cross section [76]. The cylindrical (length $1.5 \mathrm{~cm}$ and diameter $1 \mathrm{~cm}$ ) cordierite monoliths had square channels, a cell density of 62 cells $\mathrm{cm}^{-2}$ (400 cpsi) and a wall thickness of $0.18 \mathrm{~mm}$. Then, a thin carbon layer was deposited by carbonization of a polyfurfuryl alcohol (PFA) coating. The total carbon content of HPM was $6.3 \mathrm{wt} . \%$.

The cordierite monoliths were also coated with a $\gamma-\mathrm{Al}_{2} \mathrm{O}_{3}$ layer $(11 \mathrm{wt} . \%)$ by dip-coating method to yield A monoliths. For ACNF monoliths, Ni (2 wt.\%) was firstly deposited by equilibrium impregnation method of A monoliths with an aqueous solution of nickel (II) nitrate. After drying, these materials were calcined at $400{ }^{\circ} \mathrm{C}$ for $2 \mathrm{~h}$ and after in situ reduction for $1 \mathrm{~h}$ at $550{ }^{\circ} \mathrm{C}, \mathrm{CNF}$ were grown on the monoliths under ethylene $/ \mathrm{N}_{2}$ atmosphere for $4 \mathrm{~h}$ at the same temperature. The final content of $\mathrm{CNF}$ in the monoliths was 3.3 wt. $\%$.

Two composite carbon/ceramic monoliths, WA and WB, (purchased from MeadWestvaco Corporation, USA), were also used as catalyst supports. Both monoliths had a cell density of $400 \mathrm{cpsi}$, length $1.5 \mathrm{~cm}$, diameter $1 \mathrm{~cm}$ and a total carbon content of 34.7 and $30.9 \mathrm{wt} . \%$, respectively.

All monoliths were previously oxidized with an aqueous solution of $\mathrm{H}_{2} \mathrm{O}_{2} 9.8 \mathrm{M}$ for $24 \mathrm{~h}$ at room temperature to create anchoring sites for metal deposition. The catalysts were deposited on the monoliths by equilibrium impregnation method of the support with an aqueous solution of $\left[\mathrm{Pt}\left(\mathrm{NH}_{3}\right)_{4}\right]\left(\mathrm{NO}_{3}\right)_{2}$ or $\left[\mathrm{Pd}\left(\mathrm{NH}_{3}\right)_{4}\right]\left(\mathrm{NO}_{3}\right)_{2}$, obtaining the corresponding monolithic catalysts. The catalysts will be labelled in the text by using the support name (HPM, WA, WB, A or ACNF) and the metal deposited (Pd or Pt). Prior to characterization or reaction, the catalysts were also reduced in $\mathrm{H}_{2}$ flow at $300{ }^{\circ} \mathrm{C}$ for $3 \mathrm{~h}$.

\subsection{Characterization of Supports and Catalysts}

The carbonization processes were simulated by thermogravimetric (TG) analysis under $\mathrm{N}_{2}$ flow using a Shimadzu thermobalance model TGA-50H. The morphology of the samples and adherence of the coatings deposited onto cordierite monoliths were analyzed by scanning electron microscopy (SEM) with a Leo (Carl Zeiss) Gemini-1530 microscopy

Textural characterization was carried out using mercury porosimetry (Quantachrome Autoscan-60) and physical adsorption of $\mathrm{N}_{2}$ at $-196{ }^{\circ} \mathrm{C}$ and $\mathrm{CO}_{2}$ at $0{ }^{\circ} \mathrm{C}$ (Quantachrome Autosorb-1). From mercury porosimetry data, $V_{\text {meso }}$ and $V_{\text {macro }}$ were calculated, which correspond to the volume of pores with diameter between $3.7-50 \mathrm{~nm}$ and with diameter larger than $50 \mathrm{~nm}$, respectively. The external surface 
area $\left(S_{\text {ext }}\right)$ is due to macropores and mainly mesopores, previously estimated from mercury porosimetry. The BET and Dubinin-Radushkevich equations were applied to the corresponding adsorption isotherms, $S_{\text {BET }}$ and $S_{\mathrm{CO} 2}$ being determined, respectively [77].

The immersion enthalpies into water of the previously outgassed samples $\left(110^{\circ} \mathrm{C}\right.$ for $\left.12 \mathrm{~h}\right)$ were measured at $30{ }^{\circ} \mathrm{C}$ with an isothermal calorimeter of Tian-Calvet type (Setaram C-80). Corrections corresponding to the bulb breaking energy and to the liquid vaporization energy were also taken into account [78].

The surface chemistry of the supports was characterized by temperature programmed desorption (TPD) and measurements of pHpzc (point of zero charge). TPD experiments were carried out by heating the samples to $1000{ }^{\circ} \mathrm{C}$ in $\mathrm{He}$ flow at a heating rate of $5{ }^{\circ} \mathrm{C} \mathrm{min}-1$. The amount of evolved gases was recorded as a function of temperature using a quadrupole mass spectrometer (Balzers, model Thermocube), as described elsewhere [61]. The oxygen content ( $\left.\mathrm{O}_{\mathrm{TPD}}\right)$ was calculated from the amounts of $\mathrm{CO}$ and $\mathrm{CO}_{2}$ evolved during the TPD experiments.

Pt dispersion (D) and average $\mathrm{Pt}$ particle size $(\mathrm{dPt})$ were obtained by $\mathrm{H}_{2}$ chemisorption at $25{ }^{\circ} \mathrm{C}$ and high resolution transmission microscopy ( $\mathrm{dPt}_{\mathrm{Pt}}$ HRTEM). Pt dispersion was obtained from the amount of $\mathrm{H}_{2}$ chemisorbed assuming a stoichiometric ratio of $\mathrm{H}_{2}: \mathrm{Pt}=1: 2$ (dissociative chemisorption) and the average particle sizes were calculated as $\mathrm{dPt}_{\mathrm{Pt}}=1.08 / \mathrm{D}(\mathrm{nm})$. HRTEM images were acquired with a Phillips CM-20 electron microscope.

\subsection{Gas-Phase Catalytic Combustion of BTX}

The catalytic combustion of BTX and acetone was performed in a glass, U-shaped, reactor operated in continuous mode at atmospheric pressure. In a typical run, certain amount of catalyst was placed in the reactor and a feed stream containing $\mathrm{He} / \mathrm{O}_{2}$ mixture $(80 / 20 \%)$ was saturated with the hydrocarbon by bubbling through a saturator filled with VOCs cooled at a determined temperature. The total flow of the feed stream was controlled by a flow controller and the reaction was studied at temperatures ranging from 110 to $190^{\circ} \mathrm{C}$.

Analysis of the reaction products was carried out by using a Perkin Elmer (mod. 8500) gas chromatograph (GC) with a thermal conductivity detector and Paraplot Q capillary column. The only primary products found were $\mathrm{CO}_{2}$ and $\mathrm{H}_{2} \mathrm{O}$, which were also confirmed by mass spectrometry. In all cases, conversion was calculated by VOCs consumption and formation to $\mathrm{CO}_{2}$.

\section{Conclusions}

This review has established that carbon supports have shown high efficiency in the development of combustion catalysts. Different types of carbon materials, including carbon aerogels, carbon nanofibers and carbon coatings or structured carbon monoliths with different porosity and surface chemistry were used to develop specific combustion catalysts, when used as support of noble metals (Pt and Pd). Different series of catalysts were prepared, characterized and tested in the combustion of aromatics BTX and acetone. In all cases, total combustion is reached below $190{ }^{\circ} \mathrm{C}$ and selectively to $\mathrm{CO}_{2}$, in spite that the VOCs conversion depends on both VOCs nature and concentration.

The gas-phase catalytic combustion of VOCs is clearly a structure-sensitive reaction, being the active phase dispersion the most influencing parameter. Therefore, the temperature and atmosphere of catalyst pretreatment should be carefully fitted, since its activity increases as the Pt particle size increases, at 
least up to $10 \mathrm{~nm}$ (minimum dispersion studied in the present work). The catalyst activation occurs along the combustion reaction and due to the increasing sintering. However, very large particles should lead to a decrease of activity.

Support mesoporosity favors markedly the active phase dispersion and the concentration of adsorbed molecules. The hydrophobicity changes induced by oxidation treatments of carbon materials have a weak effect on the catalyst performance. Oxidized supports seem also to increase the activity of the supported catalyst, but it is mainly due to the loss of metal dispersion induced by the release of less stable oxygen-containing surface groups acting as Pt anchoring sites. Nevertheless, the influence of the support hydrophobicity on the catalyst performance was clearly pointed out by comparing carbon and inorganic supports, since inorganic supports (e.g., alumina) presented a lower activity due to the high water adsorption capacity, leading to the deactivation of active sites regarding to those supported on carbon materials.

\section{Author Contributions}

All the authors of this manuscript participate in the development of the experimental works, including materials and equipment management, analysis and redaction of results for publication.

\section{Conflicts of Interest}

The authors declare no conflict of interest.

\section{References}

1. Berenjian, A.; Chan, N.; Malmiri, H.J. Volatile Organic Compounds removal methods: A review. Am. J. Biochem. Biotechnol. 2012, 8, 220-229.

2. Huang, H.; Xu, Y.; Feng, Q.; Leung, D.Y.C. Low temperature catalytic oxidation of volatile organic compounds: A review. Catal. Sci. Technol. 2015, doi:10.1039/C4CY01733A.

3. Spivey, J.J. Complete catalytic oxidation of volatile organics. Ind. Eng. Chem. Res. 1987, 26, 2165-2180.

4. García, T.; Solsona, B.; Taylor, S.H. Naphthalene total oxidation over metal oxide catalysts. Appl. Catal. B 2006, 66, 92-99.

5. Kim, S.C.; Park, C.Y. The complete oxidation of a volatile organic compound (toluene) over supported metal oxide catalysts. Res. Chem. Intermediates 2002, 28, 441-449.

6. Kulkarni, D.; Wachs, I.E. Isopropanol oxidation by pure metal oxide catalysts: Number of active surface sites and turnover frequencies. Appl. Catal. A 2002, 237, 121-137.

7. Li, W.B.; Chu, W.B.; Zhuang, M.; Hua, J. Catalytic oxidation of toluene on Mn-containing mixed oxides prepared in reverse microemulsions. Catal. Today 2004, 93-95, 205-209.

8. Barbero, B.P.; Costa-Almeida, L.; Sanz, O.; Morales, M.R.; Cadus, L.E.; Montes, M. Washcoating of metallic monoliths with a $\mathrm{MnCu}$ catalyst for catalytic combustion of volatile organic compounds. Chem. Eng. J. 2008, 139, 430-435.

9. $\mathrm{Hu}, \mathrm{C}$; $\mathrm{Zhu}, \mathrm{Q}$; Jiang, Z. Nanosized $\mathrm{CuO}-\mathrm{Zr}_{x} \mathrm{Ce}_{1-x} \mathrm{O}_{\mathrm{y}}$ aerogel catalysts prepared by ethanol supercritical drying for catalytic deep oxidation of benzene. Powder Technol. 2009, 194, 109-114. 
10. Kim, S.C.; Shim, W.G. Catalytic combustion of VOCs over a series of manganese oxide catalysts. Appl. Catal. B 2010, 98, 180-185.

11. Santos, V.P.; Pereira, M.F.R.; Órfão, J.J.M.; Figueiredo, J.L. The role of lattice oxygen on the activity of manganese oxides towards the oxidation of volatile organic compounds. Appl. Catal. B 2010, 99, 353-363.

12. Yang, P.; Yang, S.; Shi, Z.; Meng, Z.; Zhou, R. Deep oxidation of chlorinated VOCs over $\mathrm{CeO}_{2}$-based transition metal mixed oxide catalysts. Appl. Catal. B 2015, 162, 227-235.

13. Sinha, A.K.; Suzuki, K. Three-dimensional mesoporous chromium oxide: A highly efficient material for the elimination of volatile organic compounds. Angew. Chemie Int. Ed. 2005, 44, 271-273.

14. Jones, J.; Ross, J.R.H. The development of supported vanadia catalysts for the combined catalytic removal of the oxides of nitrogen and of chlorinated hydrocarbons from flue gases. Catal. Today 1997, 35, 97-105.

15. Liotta, L.F. Catalytic oxidation of volatile organic compounds on supported noble metals. Appl. Catal. B 2010, 100, 403-412.

16. Li, W.B.; Wang, J.X.; Gong, H. Catalytic combustion of VOCs on non-noble metal catalysts. Catal. Today 2009, 148, 81-87.

17. Papaefthimiou, P.; Ioannides, T.; Verykios, X.E. Performance of doped $\mathrm{Pt} / \mathrm{TiO}_{2}\left(\mathrm{~W}^{6+}\right)$ catalysts for combustion of volatile organic compounds (VOCS). Appl. Catal. B 1998, 15, 75-92.

18. Gélin, P.; Primet, M. Complete oxidation of methane at low temperature over noble metal based catalysts: A review. Appl. Catal. B 2002, 39, 1-37.

19. Patterson, M.J.; Angove, D.E.; Cant, N.W. The effect of carbon monoxide on the oxidation of four C6 to C8 hydrocarbons over platinum, palladium and rhodium. Appl. Catal. B 2000, 26, 47-57.

20. Li, N.; Gaillard, F.; Boréave, A. Electrochemical promotion of Ag catalyst for the low temperature combustion of toluene. Catal. Commun. 2008, 9, 1439-1442.

21. Scirè, S.; Liotta, L.F. Supported gold catalysts for the total oxidation of volatile organic compounds. Appl. Catal. B 2012, 125, 222-246.

22. Carabineiro, S.A.C.; Chen, X.; Martynyuk, O.; Bogdanchikova, N.; Avalos-Borja, M.; Pestryakov, A.; Tavares, P.B.; Órfão, J.J.M.; Pereira, M.F.R.; Figueiredo, J.L. Gold supported on metal oxides for volatile organic compounds total oxidation. Catal. Today 2015, 244, 103-114.

23. Kim, K.J.; Boo, S.I.; Ahn, H.G. Preparation and characterization of the bimetallic Pt-Au/ $\mathrm{ZnO} / \mathrm{Al}_{2} \mathrm{O}_{3}$ catalysts: Influence of Pt-Au molar ratio on the catalytic activity for toluene oxidation. J. Ind. Eng. Chem. 2009, 15, 92-97.

24. Dos Santos, A.A.; Lima, K.M.N.; Figueiredo, R.T.; Egues, S.M.D.S.; Ramos, A.L.D. Toluene deep oxidation over noble metals, Copper and Vanadium Oxides. Catal. Lett. 2007, 114, 59-63.

25. Santos, V.P.; Carabineiro, S.A.C.; Tavares, P.B.; Pereira, M.F.R.; Órfão, J.J.M.; Figueiredo, J.L. Oxidation of $\mathrm{CO}$, ethanol and toluene over $\mathrm{TiO}_{2}$ supported noble metal catalysts. Appl. Catal. B 2010, 99, 198-205.

26. Escandón, L.S.; Ordóñez, S.; Vega, A.; Díez, F.V. Sulphur poisoning of palladium catalysts used for methane combustion: Effect of the support. J. Hazard. Mater. 2008, 153, 742-750.

27. Debecker, D.P.; Farin, B.; Gaigneaux, E.M.; Sanchez, C.; Sassoye, C. Total oxidation of propane with a nano- $\mathrm{RuO}_{2} / \mathrm{TiO}_{2}$ catalyst. Appl. Catal. A 2014, 481, 11-18. 
28. Yazawa, Y.; Takagi, N.; Yoshida, H.; Komai, S.-i.; Satsuma, A.; Tanaka, T.; Yoshida, S.; Hattori, T. The support effect on propane combustion over platinum catalyst: Control of the oxidation-resistance of platinum by the acid strength of support materials. Appl. Catal. A 2002, 233, 103-112.

29. Yazawa, Y.; Yoshida, H.; Takagi, N.; Komai, S.-i.; Satsuma, A.; Hattori, T. Acid Strength of Support Materials as a Factor Controlling Oxidation State of Palladium Catalyst for Propane Combustion. J. Catal. 1999, 187, 15-23.

30. Zhang, C.; He, H. A comparative study of $\mathrm{TiO}_{2}$ supported noble metal catalysts for the oxidation of formaldehyde at room temperature. Catal. Today 2007, 126, 345-350.

31. An, N.; Wu, P.; Li, S.; Jia, M.; Zhang, W. Catalytic oxidation of formaldehyde over $\mathrm{Pt} / \mathrm{Fe}_{2} \mathrm{O}_{3}$ catalysts prepared by different method. Appl. Surface Sci. 2013, 285, Part B, 805-809.

32. Yu, X.; He, J.; Wang, D.; Hu, Y.; Tian, H.; He, Z. Facile Controlled Synthesis of Pt/MnO 2 Nanostructured Catalysts and Their Catalytic Performance for Oxidative Decomposition of Formaldehyde. J. Phys. Chem. C 2012, 116, 851-860.

33. Minicò, S.; Scirè, S.; Crisafulli, C.; Maggiore, R.; Galvagno, S. Catalytic combustion of volatile organic compounds on gold/iron oxide catalysts. Appl. Catal. B 2000, 28, 245-251.

34. Haruta, M. Size- and support-dependency in the catalysis of gold. Catal. Today 1997, 36, 153-166.

35. Centeno, M.A.; Paulis, M.; Montes, M.; Odriozola, J.A. Catalytic combustion of volatile organic compounds on $\mathrm{Au} / \mathrm{CeO}_{2} / \mathrm{Al}_{2} \mathrm{O}_{3}$ and $\mathrm{Au} / \mathrm{Al}_{2} \mathrm{O}_{3}$ catalysts. Appl. Catal. A 2002, 234, 65-78.

36. Ousmane, M.; Liotta, L.F.; Carlo, G.D.; Pantaleo, G.; Venezia, A.M.; Deganello, G.; Retailleau, L.; Boreave, A.; Giroir-Fendler, A. Supported Au catalysts for low-temperature abatement of propene and toluene, as model VOCs: Support effect. Appl. Catal. B 2011, 101, 629-637.

37. Wu, H.; Wang, L.; Zhang, J.; Shen, Z.; Zhao, J. Catalytic oxidation of benzene, toluene and p-xylene over colloidal gold supported on zinc oxide catalyst. Catal. Commun. 2011, 12, 859-865.

38. Scirè, S.; Minicò, S.; Crisafulli, C. Pt catalysts supported on H-type zeolites for the catalytic combustion of chlorobenzene. Appl. Catal. B 2003, 45, 117-125.

39. Xia, Q.H.; Hidajat, K.; Kawi, S. Adsorption and catalytic combustion of aromatics on platinum-supported MCM-41 materials. Catal. Today 2001, 68, 255-262.

40. Aznárez, A.; Delaigle, R.; Eloy, P.; Gaigneaux, E.M.; Korili, S.A.; Gil, A. Catalysts based on pillared clays for the oxidation of chlorobenzene. Catal. Today 2015, 246, 15-27.

41. Gil, A.; Vicente, M.A.; Korili, S.A. Effect of the nature and structure of pillared clays in the catalytic behaviour of supported manganese oxide. Catal. Today 2006, 112, 117-120.

42. Giraudon, J.M.; Elhachimi, A.; Leclercq, G. Catalytic oxidation of chlorobenzene over Pd/perovskites. Appl. Catal. B 2008, 84, 251-261.

43. Arzamendi, G.; de la Peña O'Shea, V.A.; Álvarez-Galván, M.C.; Fierro, J.L.G.; Arias, P.L.; Gandía, L.M. Kinetics and selectivity of methyl-ethyl-ketone combustion in air over alumina-supported $\mathrm{PdO}_{x}-\mathrm{MnO}_{x}$ catalysts. J. Catal. 2009, 261, 50-59.

44. Takeguchi, T.; Aoyama, S.; Ueda, J.; Kikuchi, R.; Eguchi, K. Catalytic combustion of volatile organic compounds on supported precious metal catalysts. Top. Catal. 2003, 23, 159-162.

45. Marécot, P.; Fakche, A.; Kellali, B.; Mabilon, G.; Prigent, P.; Barbier, J. Propane and propene oxidation over platinum and palladium on alumina: Effects of chloride and water. Appl. Catal. B 1994, 3, 283-294. 
46. Papaefthimiou, P.; Ioannides, T.; Verykios, X.E. Catalytic incineration of volatile organic compounds Present in industrial waste streams. Appl. Therm. Eng. 1998, 18, 1005-1012.

47. Wu, J.C.S.; Chang, T.Y. VOC deep oxidation over Pt catalysts using hydrophobic supports. Catal. Today 1998, 44, 111-118.

48. Wu, J.C.S.; Lin, Z.A.; Tsai, F.M.; Pan, J.W. Low-temperature complete oxidation of BTX on Pt/activated carbon catalysts. Catal. Today 2000, 63, 419-426.

49. Shim, W.G.; Kim, S.C. Heterogeneous adsorption and catalytic oxidation of benzene, toluene and xylene over spent and chemically regenerated platinum catalyst supported on activated carbon. Appl. Surf. Sci. 2010, 256, 5566-5571.

50. Bedia, J.; Rosas, J.M.; Rodríguez-Mirasol, J.; Cordero, T. Pd supported on mesoporous activated carbons with high oxidation resistance as catalysts for toluene oxidation. Appl. Catal. B 2010, 94, $8-18$.

51. Huang, S.; Zhang, C.; He, H. In situ adsorption-catalysis system for the removal of o-xylene over an activated carbon supported Pd catalyst. J. Environ. Sci. 2009, 21, 985-990.

52. Jamalzadeh, Z.; Haghighi, M.; Asgari, N. Synthesis and physicochemical characterizations of nanostructured $\mathrm{Pd}$ /carbon-clinoptilolite- $\mathrm{CeO}_{2}$ catalyst for abatement of xylene from waste gas streams at low temperature. J. Ind. Eng. Chem. 2014, 20, 2735-2744.

53. Liu, Z.-S.; Chen, J.-Y.; Peng, Y.-H. Activated carbon fibers impregnated with Pd and Pt catalysts for toluene removal. J. Hazard. Mater. 2013, 256-257, 49-55.

54. Joung, H.-J.; Kim, J.-H.; Oh, J.-S.; You, D.-W.; Park, H.-O.; Jung, K.-W. Catalytic oxidation of VOCs over CNT-supported platinum nanoparticles. Appl. Surf. Sci. 2014, 290, 267-273.

55. Lu, C.-Y.; Wei, M.-C.; Chang, S.-H.; Wey, M.-Y. Study of the activity and backscattered electron image of Pt/CNTs prepared by the polyol process for flue gas purification. Appl. Catal. A 2009, $354,57-62$.

56. Maldonado-Hodar, F.J.; Moreno-Castilla, C.; Perez-Cadenas, A.F. Catalytic combustion of toluene on platinum-containing monolithic carbon aerogels. Appl. Catal. B 2004, 54, 217-224.

57. Maldonado-Hódar, F.J.; Ferro-García, M.A.; Rivera-Utrilla, J.; Moreno-Castilla, C. Synthesis and textural characteristics of organic aerogels, transition-metal-containing organic aerogels and their carbonized derivatives. Carbon 1999, 37, 1199-1205.

58. Veser, G.; Ziauddin, M.; Schmidt, L.D. Ignition in alkane oxidation on noble-metal catalysts. Catal. Today 1999, 47, 219-228.

59. Maldonado-Hodar, F.J.; Moreno-Castilla, C.; Carrasco-Marin, F.; Perez-Cadenas, A.F. Reversible toluene adsorption on monolithic carbon aerogels. J. Hazard. Mater. 2007, 148, 548-552.

60. Pérez-Cadenas, A.F.; Morales-Torres, S.; Kapteijn, F.; Maldonado-Hódar, F.J.; Carrasco-Marín, F.; Moreno-Castilla, C.; Moulijn, J.A. Carbon-based monolithic supports for palladium catalysts: The role of the porosity in the gas-phase total combustion of m-xylene. Appl. Catal. B 2008, 77, 272-277.

61. Morales-Torres, S.; Maldonado-Hódar, F.J.; Pérez-Cadenas, A.F.; Carrasco-Marín, F. Design of low-temperature Pt-carbon combustion catalysts for VOC's treatments. J. Hazard. Mater. 2010, 183, 814-822. 
62. Pérez-Cadenas, A.F.; Morales-Torres, S.; Maldonado-Hódar, F.J.; Carrasco-Marín, F. Carbon-based monoliths for the catalytic elimination of benzene, toluene and m-xylene. Appl. Catal. A 2009, 366, 282-287.

63. Morales-Torres, S.; Pérez-Cadenas, A.F.; Kapteijn, F.; Carrasco-Marín, F.; Maldonado-Hódar, F.J.; Moulijn, J.A. Palladium and platinum catalysts supported on carbon nanofiber coated monoliths for low-temperature combustion of BTX. Appl. Catal. B 2009, 89, 411-419.

64. Maldonado-Hódar, F.J. Removing aromatic and oxygenated VOCs from polluted air stream using Pt-carbon aerogels: Assessment of their performance as adsorbents and combustion catalysts. J. Hazard. Mater. 2011, 194, 216-222.

65. Tsou, J.; Magnoux, P.; Guisnet, M.; Órfão, J.J.M.; Figueiredo, J.L. Oscillations in the catalytic oxidation of volatile organic compounds. J. Catal. 2004, 225, 147-154.

66. O'Malley, A.; Hodnett, B.K. The influence of volatile organic compound structure on conditions required for total oxidation. Catal. Today 1999, 54, 31-38.

67. Padilla-Serrano, M.N.; Maldonado-Hodar, F.J.; Moreno-Castilla, C. Influence of Pt particle size on catalytic combustion of xylenes on carbon aerogel-supported Pt catalysts. Appl. Catal. B 2005, 61, 253-258.

68. Ubago-Pérez, R.; Carrasco-Marín, F.; Moreno-Castilla, C. Carbon-supported Pt as catalysts for low-temperature methanol decomposition to carbon monoxide and hydrogen. Appl. Catal. A 2004, 275, 119-126.

69. Dalla Betta, R.A.; Boudart, M. Well-Dispersed platinum on Y Zeolite: Preparation and Catalytic Activity. Proceedings of 5th International Congress on Catalysis, Palm Beach, FL, USA, 21-25 August 1972; pp.1329-1341.

70. Richard, M.A.; Pancirov, R.J. Thermal decomposition of tetraamineplatinum(II) chloride by simultaneous TG/DTG/DTA/MS and direct insertion probe mass spectrometry. J. Therm. Anal. 1987, 32, 825-834.

71. Garetto, T.F.; Apesteguía, C.R. Oxidative catalytic removal of hydrocarbons over $\mathrm{Pt} / \mathrm{Al}_{2} \mathrm{O}_{3}$ catalysts. Catal. Today 2000, 62, 189-199.

72. Garetto, T.F.; Apesteguía, C.R. Structure sensitivity and in situ activation of benzene combustion on Pt/A12O3 catalysts. Appl. Catal. B 2001, 32, 83-94.

73. Moreno-Castilla, C.; Ferro-Garcia, M.A.; Joly, J.P.; Bautista-Toledo, I.; Carrasco-Marin, F.; Rivera-Utrilla, J. Activated Carbon Surface Modifications by Nitric Acid, Hydrogen Peroxide, and Ammonium Peroxydisulfate Treatments. Langmuir 1995, 11, 4386-4392.

74. Slasli, A.M.; Jorge, M.; Stoeckli, F.; Seaton, N.A. Modelling of water adsorption by activated carbons: Effects of microporous structure and oxygen content. Carbon 2004, 42, 1947-1952.

75. Morales-Torres, S.; Maldonado-Hódar, F.J.; Pérez-Cadenas, A.F.; Carrasco-Marín, F. Textural and mechanical characteristics of carbon aerogels synthesized by polymerization of resorcinol and formaldehyde using alkali carbonates as basification agents. Phys. Chem. Chem. Phys. 2010, 12, 10365-10372.

76. Perez-Cadenas, A.F.; Kapteijn, F.; Moulijn, J.A. Tuning the morphology of monolith coatings. Appl. Catal. A 2007, 319, 267-271.

77. Bansal, R.C.; Donnet, J.B.; Stoeckli, F. Active Carbon; Marcel Dekker: New York, NY, USA, 1988. 
78. Denoyel, R.; Fernandez-Colinas, J.; Grillet, Y.; Rouquerol, J. Assessment of the surface area and microporosity of activated charcoals from immersion calorimetry and nitrogen adsorption data. Langmuir 1993, 9, 515-518.

(C) 2015 by the authors; licensee MDPI, Basel, Switzerland. This article is an open access article distributed under the terms and conditions of the Creative Commons Attribution license (http://creativecommons.org/licenses/by/4.0/). 